\title{
39. GEOPHYSICAL AGING OF OCEANIC CRUST: EVIDENCE FROM HOLE 801C ${ }^{1}$
}

\author{
Richard D. Jarrard, ${ }^{2}$ Roger L. Larson, ${ }^{3}$ Andrew T. Fisher ${ }^{4}$ and Lewis J. Abrams ${ }^{5}$
}

\begin{abstract}
The hydrologic evolution of oceanic crust, from vigorous hydrothermal circulation in young, permeable volcanic crust to reduced circulation in old, cooler crust, is thought to cause a corresponding evolution of geophysical properties such as velocity, density, and resistivity. This geophysical aging has been studied previously by comparing young and old crust formed at a slow spreading rate, as well as young crust formed at a moderate-to-fast spreading rate. Here we extend this analysis to the upper 131 $\mathrm{m}$ of volcanic crust at Hole $801 \mathrm{C}$ - old crust formed at a spreading rate faster than that of crust in previous studies.

The geophysical aging of the upper basaltic crust at Hole $801 \mathrm{C}$ includes competing changes on intergranular and intraflow scales. At the intergranular scale, as seen by laboratory measurements on $2.5-\mathrm{cm}$ core plugs, greater basalt alteration increases porosity and decreases matrix velocity and matrix density; alteration therefore dramatically decreases bulk velocity and bulk density. The same alteration effects on matrix properties are evident at the intraflow and interflow scale, as seen by logging tools with $\sim 0.5$ - $\mathrm{m}$ vertical resolution, although that scale includes macroporosity unsampled by core plugs. Average velocities and densities measured in plugs and logs agree, possibly because alteration has filled cracks and interpillow voids, thereby reducing macroporosity and increasing velocity and density. This meter-scale increase in velocity and density may dominate the plug-scale reductions, so that the average upper crustal properties at Hole $801 \mathrm{C}$ are as expected for very old crust: substantial alteration resulting in layer-2b velocities. Alternatively, the agreement between plugs and $\operatorname{logs}$, as well as the observation of layer- $2 \mathrm{~b}$ velocities, may primarily be the result of the strong predominance of flows over pillows, because flows have much lower initial porosity than do pillows.

Geochemical and geophysical logs discriminate three zones in the logged basement interval at Hole 801C: an upper sequence of altered alkalic basalts, a lower interval of tholeiites, and an intervening zone of hydrothermal precipitate and associated extensive basalt alteration. Imaging logs delineate the pervasive horizontal layering of filled fractures and of flow boundaries. A fossil hydrothermal zone, with predominantly silicon and iron composition and with extremely heterogeneous geophysical properties, includes some porosities and conductivities that are far above those expected in old oceanic crust.
\end{abstract}

\section{INTRODUCTION}

The standard model for the hydrologic evolution of oceanic crust is elegantly simple and qualitatively accounts for many geophysical observations. Newly created oceanic crust is very hot, very porous, and very permeable, with both intergranular porosity (microcracks and vesicles) and macroporosity (interpillow voids and fractures). Hydrothermal circulation is vigorous in young crust near the ridge crest, resulting in black smokers on the seafloor and alteration of the upper several kilometers. Crustal alteration fills cracks and interpillow voids, causing velocities and densities to increase, whereas porosity and permeability decrease and magnetic minerals oxidize.

The geophysical aging of Atlantic and Pacific oceanic crusts appears to be quite different (Houtz and Ewing, 1976), presumably because of their different spreading rates. To decipher the interactions among hydrogeology, structure, and physical properties in the aging of oceanic crust, we must examine at least four typical end-member situations: young crust created at slow and fast spreading rates, and old crust created at slow and fast spreading rates. The first three of these situations were partly addressed at Holes 395A (young and slow), 504B (young and moderate-to-fast), and 418A (old and slow).

The missing end member has been old crust formed at a fast spreading rate. Until now, Hole 765D offshore northwestern Australia was the site that came closest to filling this need. Hole 765D, however, sampled the first crust created after continental separation, so it

\footnotetext{
${ }^{1}$ Haggerty, J.A., Premoli Silva, I., Rack, F., and McNutt, M.K. (Eds.), 1995. Proc. ODP, Sci. Results, 144: College Station, TX (Ocean Drilling Program).

2 Department of Geology and Geophysics, University of Utah, Salt Lake City, UT 84112, U.S.A.

${ }^{3}$ Graduate School of Oceanography, University of Rhode Island, Narragansett, RI 02882, U.S.A.

${ }^{4}$ Indiana Geological Survey and Department of Geological Sciences, 611 North Walnut Grove, Bloomington IN 47405, U.S.A.

${ }^{5}$ Departamento de Geologia, Universidad de Puerto Rico, P.O. Box 5000, Mayaguez, Puerto Rico, 00681-5000.
}

may not be representative of typical oceanic crust; further, its spreading rate was only $3.7 \mathrm{~cm} / \mathrm{yr}$ (Sager et al., 1992). Leg 129 drilled a potential new end member: Site 801, in the Pigafetta Basin, northwest Pacific Ocean. Site 801 recovered the oldest in-situ oceanic crust that has been sampled to date: $166.8 \pm 4.5 \mathrm{Ma}$ (Pringle, 1992). This crust was created at a half-spreading rate of at least $8 \mathrm{~cm} / \mathrm{yr}$ (Abrams et al., 1992), close to the fastest rate $(9 \mathrm{~cm} / \mathrm{yr})$ that has been observed at currently active spreading centers. Hole $801 \mathrm{C}$ sampled an established, open-ocean spreading system, and its biostratigraphic and radiometric basement ages closely match its predicted age on the basis of extrapolating magnetic anomaly isochrons. Although basement penetration of just $131 \mathrm{~m}$ at Hole $801 \mathrm{C}$ is less than at other end-member sites, downhole measurements here can help to complete the characterization of oceanic crustal end members.

In contrast to all previous sites drilled in the northwest Pacific, Site 801 succeeded in penetrating Cretaceous volcanics and obtaining a first-time view of the remnant Jurassic Pacific Plate. Although Site 801 is a window into the Jurassic ocean crust, even there a 192-mthick section of Middle Cretaceous volcaniclastics is present in the middle of the sedimentary section. Beneath this section of volcaniclastics and beneath an apparent unconformity lies an uninterrupted section of Valanginian to Bathonian (130-165 Ma) deep-sea pelagic sediments. The basal Bathonian sediments are interbedded with extrusive basalts at the top of the igneous section.

Holes $801 \mathrm{~B}$ and $801 \mathrm{C}$ penetrated the upper $131 \mathrm{~m}$ of Jurassic basement, with $20 \mathrm{~m}$ of overlap between the two holes. The Shipboard Scientific Party (1990b) recognized 33 cooling units from the recovered cores, predominantly basalts erupted as thin flows and less commonly as pillow lavas. A fossilized iron-rich hydrothermal-sediment deposit was found about $60 \mathrm{~m}$ below the top of the basement. Basalts from above this hydrothermal deposit are alkalic basalts, which are about 10 m.y. younger (Pringle, 1992) than the MORB tholeiites from below the deposit (Floyd and Castillo, 1992). All recovered samples had been affected by low-grade and highly variable, anoxic submarine alteration, the intensity of which appears to be unrelated to 
increasing depth or lithology (Alt et al., 1992). The most highly altered basalts are directly above and below the hydrothermalsediment deposit. The cooling unit just below the hydrothermal deposit is highly fractured and extremely altered, with a late, oxidative type of alteration that is suggestive of proximity to a hydrothermal system (Alt et al., 1992). These highly altered basalts are included in an overall hydrothermal zone, probably all associated with the emplacement of the alkalic basalts.

Although Hole $801 \mathrm{C}$ was drilled during Leg 129, no downhole experiments were undertaken in the hole at that time. Leg 144 returned to this site and completed both packer (Larson et al., this volume) and logging measurements. A complete suite of in-situ geophysical logs was obtained through the upper $100 \mathrm{~m}$ of basalt, including velocity, density, neutron porosity, resistivity, 3-component magnetometer, geochemistry, and Formation MicroScanner (Schlumberger ${ }^{\mathrm{TM}}$ ) logs.

The following specific questions were addressed by the downhole measurements undertaken in Hole 801C during Leg 144.

1. What is the porosity structure (intergranular, intraflow, and interflow) of the upper crust, and how extensively has it been modified by alteration?

2. What are the relative contributions of flow morphology and alteration to the velocity structure of old crust of fast-spreading origin? Are the observations consistent with predictions of the standard model of geophysical aging of oceanic crust?

3. What is the permeability of this old crust?

4. Is the observed pattern of hydrothermal deposits explainable in terms of the measured permeability and porosity structure?

This paper addresses the first two of these four questions. A companion paper (Larson et al., this volume) addresses the final two questions. In the following sections, we first analyze the four porositysensitive logs (density, velocity, resistivity, and neutron-porosity), comparing them to each other and to core-plug data. Next we examine structural and geochemical variations, as indicated by Formation MicroScanner and geochemical logs. Finally, we examine the implications of all of these data types for average crustal geophysical structure and for the effects of alteration on evolution of this structure.

\section{DENSITY}

Density logging uses a pad-type tool that requires a good contact with the borehole wall for reliable performance. In general, density logs are very sensitive to an irregular borehole and, in particular, to washouts (enlarged portions of the hole); in both cases, loss of pad contact can occur and cause unreliable, low-density readings. Two detectors are used, both to improve measurement precision and to partially compensate for minor loss of pad contact. A real-time correction, which uses the caliper measurement, is performed, and the $\Delta \rho \log$ indicates the magnitude of this correction. Even compensated density logs may have washout effects, however. Most previous logging of oceanic crust used density tools that frequently lost pad contact with the borehole wall; consequently, these density logs were of generally poor quality (Carlson and Herrick, 1990). Beginning on Ocean Drilling Program (ODP) Leg 125, the hostile-environment lithodensity tool (Schlumberger ${ }^{\mathrm{TM}}$ ) was used. Use of this tool at Hole $801 \mathrm{C}$ resulted in a generally high-quality density $\log$. We used a combination of caliper, $\Delta \rho$, and photoelectric factor logs to identify zones with loss of pad contact and to guide deletion of associated unreliable density data.

Figure 1 shows the edited density log with core-plug measurements of Busch et al. (1992) and Wallick et al. (1992). In heterogeneous formations, plug measurements are individually nonrepresentative of the much larger volumes sampled by logs. Furthermore, comparison of plug and log measurements is hampered by depth offsets of up to $9.5 \mathrm{~m}$, resulting from low core recovery and the curatorial convention of assuming that any recovered core comes from the top portion of the cored interval. Comparisons such as Figure $1 \mathrm{can}$, however, detect broad patterns of consistency or inconsistency between the different data types, and overall consistency is the pattern revealed by Figure 1 . The extreme heterogeneity indicated by logs for the interval 509-550 mbsf precludes detailed comparison with the much smaller core plugs, beyond noting that core measurements are most heterogeneous for this same interval. In contrast, the intervals 481-509 and 550-577 mbsf are more homogeneous, based on both core and $\log$ responses, and here the log-based densities are similar to or slightly higher than plug measurements.

Formation bulk density $\left(\rho_{b}\right)$ depends on fractional porosity $(\phi)$, matrix (or grain) density $\left(\rho_{m a}\right)$, and fluid density $\left(\rho_{f}\right)$, according to the relationship

$$
\rho_{b}=\rho_{m a}(1-\phi)+\rho_{f} \times \phi .
$$

Matrix density is the average density of the minerals forming the solid part of the rock, including any alteration minerals. Fractional porosity is much more variable than matrix density and fluid density within the basalts at this site (Shipboard Scientific Party, 1990b). Thus, the density log is a relatively straightforward porosity log, and both $\rho_{m a}$ and $\rho_{f}$ often can be assumed to be constant. Equation (1) does not, however, incorporate the possibility of porosity-dependent changes in matrix density. A crossplot of matrix density vs. porosity (Fig. 2) for the Site 801 core analyses of Busch et al. (1992) indicates that matrix density decreases with increasing porosity. This decrease, which results from greater alteration in high-porosity rocks, is quantified by linear regression:

$$
\phi=1.595-0.531 \rho_{m a}, R=0.825 .
$$

Combining Equations (1) and (2) to account for the effects on bulk density of both direct porosity and porosity-dependent matrix density,

$$
\phi=1.027-0.265 \mathrm{sqrt}\left[7.53 \rho_{b}-7.67\right] .
$$

We used Equation (3) to convert the density log into a log of porosity (Fig. 3).

\section{VELOCITY}

The basalt interval at Hole $801 \mathrm{C}$ was logged with the boreholecompensated sonic tool. This tool uses two sources and two receivers to generate four source-receiver travel times at each measurement point over distances of 0.91 and $1.52 \mathrm{~m}$, with measurements made every $15 \mathrm{~cm} . P$-wave travel time is determined by a first-break thresholding criterion: the first energy exceeding a preset threshold is assumed to be that of the first $P$-wave peak. Travel time differences between measurements at the two distances yield vertical compressional-wave travel times (the inverse of velocity) with a vertical resolution of $0.6 \mathrm{~m}$. The principles and limitations of the tool are discussed by Serra (1984).

A few of the redundant measurements at each depth were obviously unreliable because of cycle skips and "road noise" (reverberations caused by tool drag over rough borehole wall). We employed a simple reprocessing algorithm (Shipboard Scientific Party, 1987) that rejected the unreliable data, permitting calculation of a more reliable velocity $\log$ (Fig. 1). This log differs in some details from the log published by Shipboard Scientific Party (1990b) because cutoff traveltimes in the latter were set slightly too high.

The reprocessed velocity log of Figure 1 appears to be of good quality, except for the intervals 500-502, 510-520, and 523-529 mbsf. None of the redundant measurements at 501 and 517-519 mbsf were reliable. Furthermore, velocities of $2.2-3.3 \mathrm{~km} / \mathrm{s}$ in the three intervals are probably too low for basalts. As discussed later, geochemical logs indicate that the interval $510-528$ mbsf is a hydrothermal zone and suggest that there is a thin sediment or alteration layer at $501 \mathrm{mbsf}$; velocities of $2.2-3.3 \mathrm{~km} / \mathrm{s}$ may not be incompatible with these lithologies. Nevertheless, we suspect that cycle skipping on the $1.52-\mathrm{m}$ source-receiver pair exaggerates the decreases in apparent 


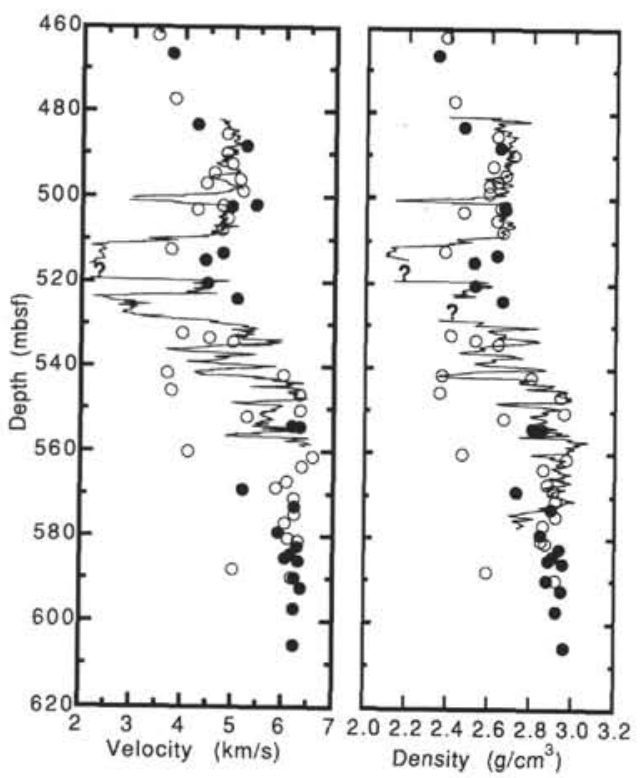

Figure 1. Edited velocity and density logs from Hole $801 \mathrm{C}$, compared with coreplug measurements. Open circles are atmospheric-pressure core measurements by Busch et al. (1992); solid circles are high-pressure measurements by Wallick et al. (1982). Velocities for the interval from 510 to $528 \mathrm{mbsf}$ may be unreliable.

velocity for the intervals 510-520 and 523-529 mbsf; the apparent rate of velocity change at these interval boundaries is too large to reconcile with the $0.6-\mathrm{m}$ measurement-averaging interval. These two intervals are confirmed to be very porous, based on a correlative drop in resistivity (and, less reliably, a density decrease and neutronporosity increase).

Sonic waveforms were recorded during data acquisition, and Moos and Ito (this volume) report the results of waveform analysis to calculate a velocity log. Moos and Ito (this volume) discuss in detail the comparison of the waveform sonic to the first-break log presented here. Agreement between the two logs is generally quite good, except in the lowest-velocity intervals, where neither approach permits confident determination of velocity. Subsequently, we use the first-break $\log$ but regard velocities of less than $3.5 \mathrm{~km} / \mathrm{s}$ as dubious.

Two studies of core physical properties are available for the basalts of Hole 801C. Busch et al. (1992) present the results of shipboard measurements of velocity, porosity, bulk density, and grain density, all at atmospheric pressure. Wallick et al. (1992) present the results of post-cruise measurements of velocity as a function of pressure and of porosity and bulk density. One might expect the latter velocity measurements to be most appropriate for comparison to in-situ logs. Crossplots of density versus velocity (Fig. 2) show, surprisingly, that the two data sets agree only when high-pressure velocity measurements of Wallick et al. (1992) are compared with atmospheric-pressure measurements of Busch et al. (1992), not when atmospheric-pressure measurements are used for both studies. We cannot explain this discrepancy, but we have used the high-pressure measurements of Wallick et al. (1992) plus the laboratory-pressure measurements of Busch et al. (1992) in core-to-log comparisons of Figure 1.

Further interlaboratory inconsistency is encountered for matrix densities and porosities. For the data of Busch et al. (1992), a crossplot of matrix density versus porosity shows a gradual decrease of matrix density with porosity increase (Fig. 2). This pattern is caused by greater alteration in the more porous rocks and has been observed in several other studies (e.g., Christensen et al., 1980; Carlson and Herrick, 1990; Jarrard and Broglia, 1991). In contrast, a similar crossplot for the data of Wallick et al. (1992) shows a large number of samples with zero porosity and widely varying grain densities, as well as generally low porosities and anomalously low grain densities in

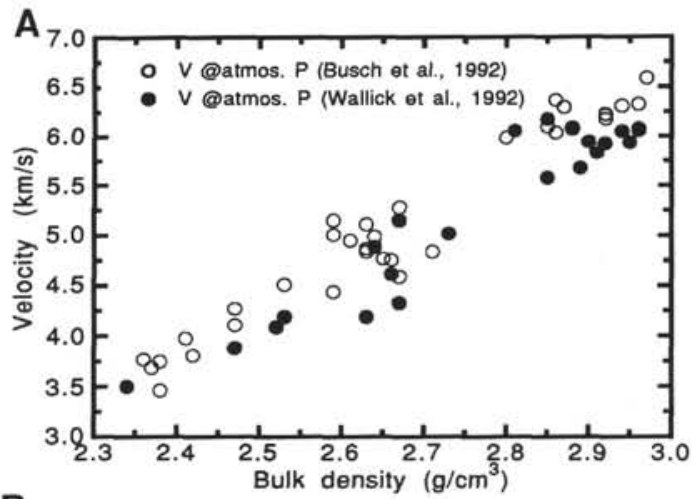

B 7.
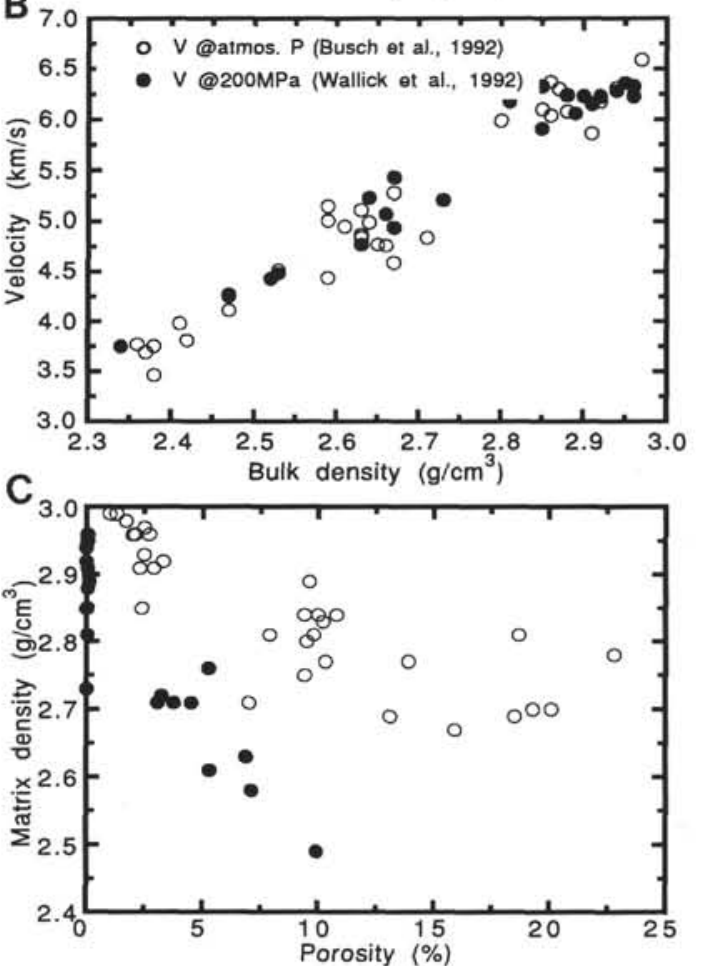

Figure 2. Interlaboratory comparison of core-based physical properties of Site 801 basalts. The velocity/density relationship obtained by Busch et al. (1992) at atmospheric pressure is more consistent with the high-pressure velocity data of Wallick et al. (1992), shown in Figure 2B, than with their atmospheric-pressure data (shown in Fig. 2A). Comparison of matrix densities to porosity (shown in Fig. 2C) suggests incomplete removal of interstitial water by Wallick et al. (1992),

several of the remaining samples. We interpret this pattern to indicate that the drying technique used by Wallick et al. (1992) failed to drive off all internal water. Consequently, we have not used these measurements of porosity and grain density.

Figure 1 compares log and core-plug measurements for velocity as a function of depth. The results of this comparison are generally similar to those previously discussed for density: consistency of core and log data in the relatively homogeneous intervals above $510 \mathrm{mbsf}$ and below 542 mbsf, contrasting with an intermediate interval in which both core and log data are too variable for useful comparison. Because the velocity logging tool was higher on the tool string than the density tool, velocity measurements were not made as deeply in Hole $801 \mathrm{C}$ as density measurements.

By far the most important variable controlling velocity in these basalts and sediments is porosity. This control is evident in core measurements (Fig. 4). Sonic traveltime ( $\Delta t$, usually expressed in $\mu \mathrm{s} / \mathrm{ft})$ is often assumed to depend on fractional porosity $(\phi)$, fluid 


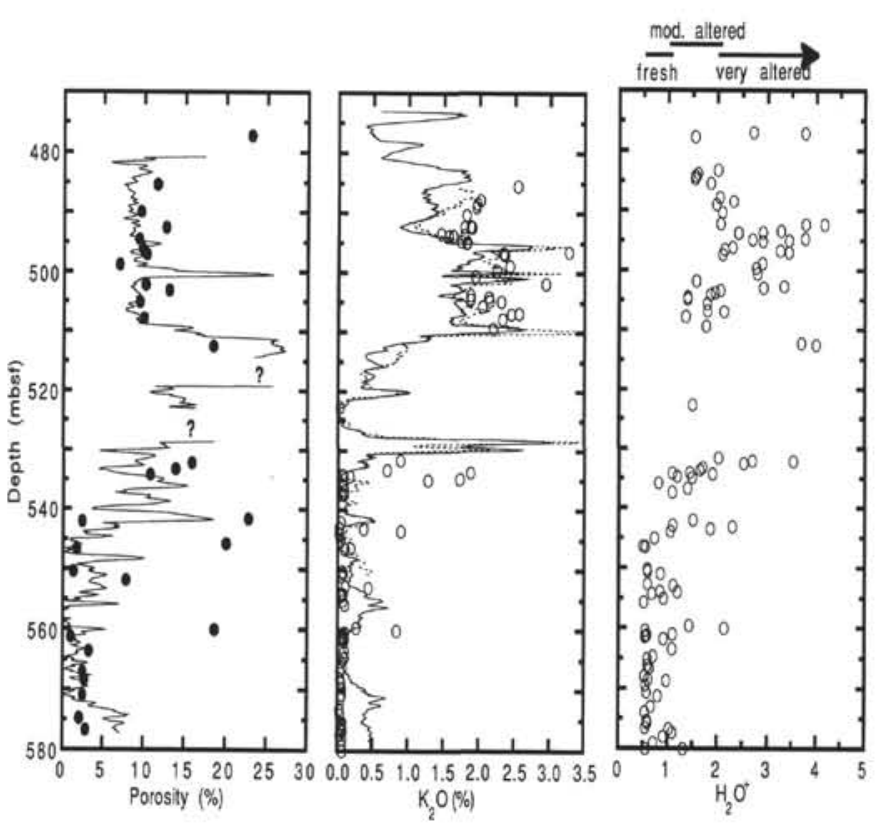

Figure 3. Relationships among porosity, potassium content, and alteration in the Site 801 basalts, based on core and log data. The porosity log is based on applying Equation (3) to the density log. Core analyses of $\mathrm{K}_{2} \mathrm{O}$ and $\mathrm{H}_{2} \mathrm{O}^{+}$are from Castillo et al. (1992); core porosity measurements are from Busch et al. (1992).

traveltime $\left(\Delta t_{f}\right)$, and matrix traveltime $\left(\Delta t_{m a}\right)$, according to the Wyllie et al. (1956) equation:

$$
\Delta t=\Delta t_{m a}(1-\phi)+\Delta t_{f} \times \phi .
$$

This equation, which has the same form as the theoretical density Equation (1), is an empirical approximation that is generally valid only in porosities lower than about $20 \%$ (e.g., Raymer et al., 1980). The Wyllie relationship ignores the influence of pore aspect ratio on velocity. The relationships of Gassmann (1951), and particularly those of Kuster and Toksöz (1974) and Toksöz et al. (1976), are more theoretically satisfying but less useful for our purposes because of their needs for additional parameters (e.g., elastic moduli). Matrix traveltimes for basalts have been estimated by other investigators (e.g., Serra, 1986). Actually, matrix velocity varies slightly within these basalts because of changes in composition (particularly proportion of mafic minerals) and, more importantly, variations in extent of alteration (Fig. 4). Fluid velocity also varies slightly, as a result of variations in residual drilling mud and temperature, but this contribution is small within the logged interval at Hole 801C.

Figure 5 plots log velocity versus porosity, calculated from density using Equation (3). Predicted velocity/porosity relationships for constant matrix velocities of 7 and $6 \mathrm{~km} / \mathrm{s}$ are shown as lines. Points below about $4 \mathrm{~km} / \mathrm{s}$ are suspect, implying very low matrix velocities attributable to either hydrothermal deposits or failure of the first-break measurement technique. The overall pattern of Figure 5 confirms that based on core samples (Fig. 4): velocity falls smoothly from about 6.5 $\mathrm{km} / \mathrm{s}$ at porosities of $<2 \%$ to about $5 \mathrm{~km} / \mathrm{s}$ at a porosity of $5 \%$ and to $3.5 \mathrm{~km} / \mathrm{s}$ at a porosity of about $20 \%$. Accordingly, matrix velocity drops from about $6.5-6.8 \mathrm{~km} / \mathrm{s}$ near zero porosity to about $6 \mathrm{~km} / \mathrm{s}$ at porosities of $15 \%-20 \%$. Overall, the interflow-scale velocity/porosity pattern of Figure 5 is similar to the plug-scale pattern of Figure 4.

Several other studies have examined the relationship between basalt porosity and velocity, based on core or log data. Site 801 data (Fig. 5 ) indicate much less sensitivity of velocity to porosity change than the cores from Holes 417A, 417D, and 418A (Christensen et al., 1980). In contrast, the pattern observed at Hole $801 \mathrm{C}$ indicates much greater sensitivity of velocity to porosity than the data from Hole 395A basalt cores (Hyndman et al., 1984) and Hole 418A basalt logs (Broglia and Moos, 1988); only at the lowest porosities do the three data sets agree. Carlson and Herrick (1990) reanalyzed Hole 418A porosities, empirically correcting neutron porosities for alteration using a core-based correlation of density with both porosity and porosity-dependent grain density; they obtained a velocity/porosity relationship that is reasonably close to those based on Hole $418 \mathrm{~A}$ cores (Christensen et al., 1980), Hole 801C cores, and Hole 801C logs.

The Site 801 velocity/porosity relationship also is similar to those determined for basalt core data from Southeast Asian Sites 768 and 770 (Jarrard and Broglia, 1991), except that those sites had lower matrix velocities. Those data and the Site 418 core data also exhibited an alteration imprint similar to that at Hole 801C: the highly altered plug samples were substantially lower in velocity, lower in matrix velocity, and higher in porosity than less-altered samples, suggesting that higher porosity facilitates alteration, which in turn decreases matrix velocity (Carlson and Herrick, 1990; Jarrard and Broglia, 1991). Jarrard and Schaar (1991) measured cation exchange capacity on the Site 768 and 770 core samples, obtaining a more objective measure of alteration and confirming the pattern of greater clay content in the more porous basalts.

These intersite comparisons of velocity to porosity are degraded by the heterogeneous techniques and assumptions used in calculating porosities at individual sites. Direct comparison of velocity to density avoids this inconsistency and yet maintains a focus on the control exerted by porosity on both velocity and density. Figure 6 compares the Site 801 geophysical-log data to a synthesis by Busch et al. (1992) of core-plug data from many Deep Sea Dilling Program (DSDP) and ODP sites, including Site 801 . Site 801 basement data exhibit as large a range of velocity and density as that from all other sites combined. Furthermore, cores and logs from this site show similar relationships between velocity and density.

The preferred velocity/density relationship of Carlson and Herrick (1990) does not fit the data of Figure 6. A combination of the Wyllie et al. (1956) velocity/porosity relationship with the theoretical density/porosity relationship does fit the core and log data, but not with any choice of constant matrix values. Instead, the pattern is fit with porosity-dependent matrix values. This pattern does not imply that fresh and altered rocks with the same porosity have identical velocities and densities. It does indicate that, in the first-order pattern among a suite of basalts, the more porous basalts have lower matrix density and lower matrix velocity because of the greater degree of alteration.

\section{RESISTIVITY}

Three resistivity logs with different depths of penetration (shallow, medium, and deep) were obtained at Hole 801C (Shipboard Scientific Party, 1990b). In general, resistivity logs have the highest signal-to-noise ratio of any log obtained in ODP. The shallow and medium-penetration logs are, however, sensitive to changes in hole size: in washed-out portions of the hole, they give much lower resistivity readings than does the deep-induction resistivity log. Consequently, we confine our analyses to the deep-resistivity log, which has a depth of penetration so great that it is relatively insensitive to hole-size variations.

If clays have a minor contribution to measured formation resistivity $\left(R_{o}\right)$, then $R_{o}$ is related to fractional porosity by the Archie (1942) equation, as generalized by Winsauer and McCardell (1953):

$$
R_{o} / R_{w}=a \phi^{-m},
$$

where the ratio of formation resistivity to resistivity of the formation water $\left(R_{w}\right)$ is defined as the formation factor. Estimation of $R_{w}$ is reasonably accurate if the formation temperatures and salinity are known. For most ODP holes, these near-borehole temperatures are perturbed and uncertain because of drilling-fluid circulation. In contrast, the logging of Hole $801 \mathrm{C}$ was undertaken 2.5 years after drilling, and a temperature-logging tool was attached to the first tool string to 
Observed pattern at Site 801 (at lab-sample scale)
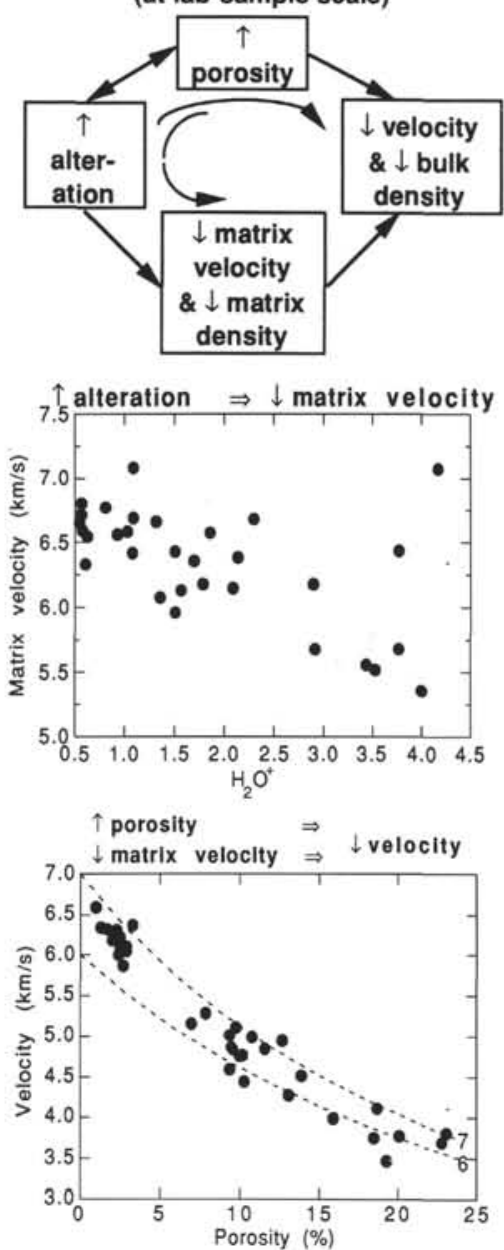
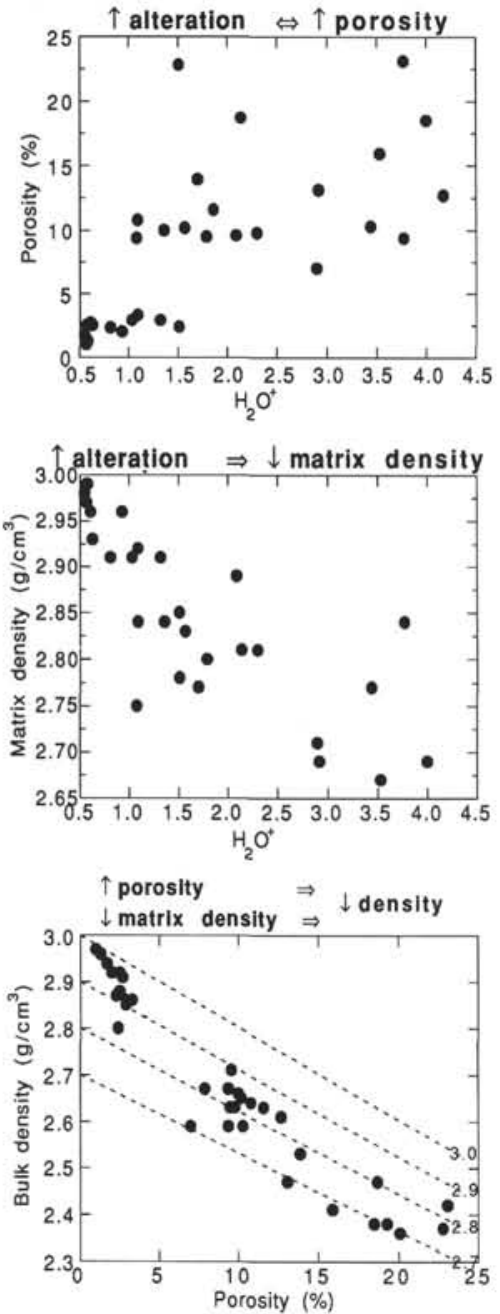

Figure 4. Effects of alteration on velocity and density at Site 801, based on the core-plug measurements of Busch et al. (1992). At the centimeter scale seen by core plugs, alteration increases porosity and decreases both matrix velocity and matrix density. Both effects lower velocity and bulk density. re-enter the hole during Leg 144. This temperature log gives an equilibrium temperature profile that indicates dominantly conductive heat flow (Larson et al., this volume) and that permits very accurate estimation of $R_{w}$

Surface conduction on clays can have a significant effect on basalt resistivity, particularly at elevated temperatures (Olhoeft, 1981). Pezard (1990), for example, used log-based estimates of both porefluid and clay conduction in his calculation of porosity from resistivity at Hole 504B. In contrast, Jarrard and Schaar (1991) evaluated the relative importance of pore-fluid and clay-surface conduction at Sites 768 and 770 by measuring resistivity and cation exchange capacity. They found that a conductivity component independent of fluid conductivity was detectable, but it was so minor that it could be neglected without substantially biasing the estimate of porosity.

Several previous studies of basalt cores or logs have used a crossplot of formation factor vs. porosity to estimate $a$ and $m$. For example, Pezard (1990) found from cores at Hole 504B that $F F=10 \phi^{-1}$. Jarrard and Schaar (1991) determined $a$ and $m$ from regression of core data and from regression of log data at Sites 768 and 770 . Their estimates of $a$ range from 2.2 to 6.5 , and their estimates of $m$ range from 1.2 to 1.6. For the very old crust of Hole 418A, Broglia and Moos (1988) found from logs that $F F=11.5 \phi^{-1.85}$ in the uppermost altered interval, and $F F=29.5 \phi^{-1.16}$ in the lower portion of that site.

Assuming that surface conduction is minor in the Site 801 basalts, we can examine the effect of porosity on formation factor with a crossplot of log-based formation factor vs. porosity, where porosity is based on applying Equation (3) to the density log. When all basement lithologies from Site 801 are plotted in this manner (Fig. 7), the data appear to indicate a very steep slope, implying that $m$ is very large

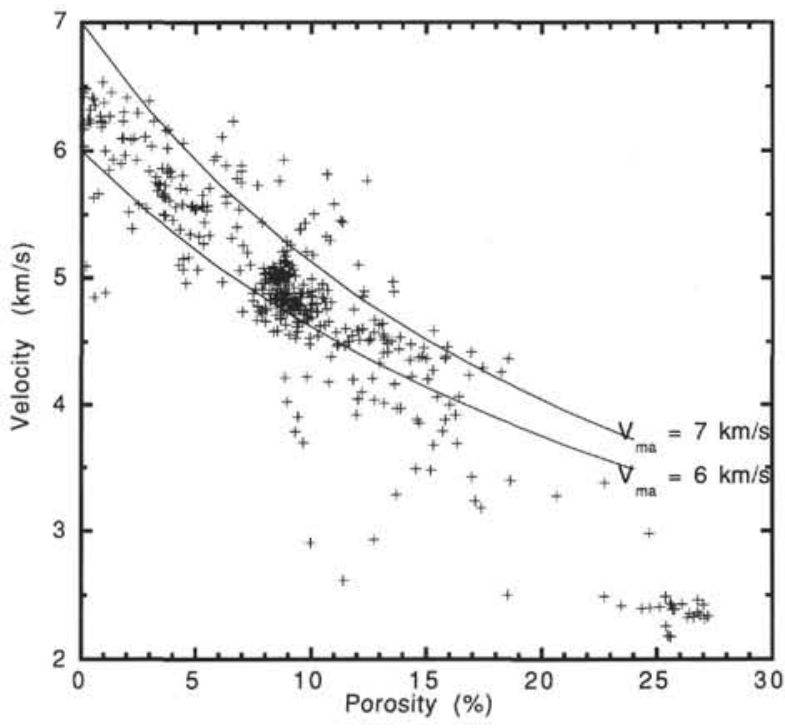

Figure 5. Log-based comparison of velocity to porosity for Site 801 basalts. Solid curves are predicted relationships for matrix velocities of 7 and $6 \mathrm{~km} / \mathrm{s}$, based on the Wyllie et al. (1956) time-average equation. 

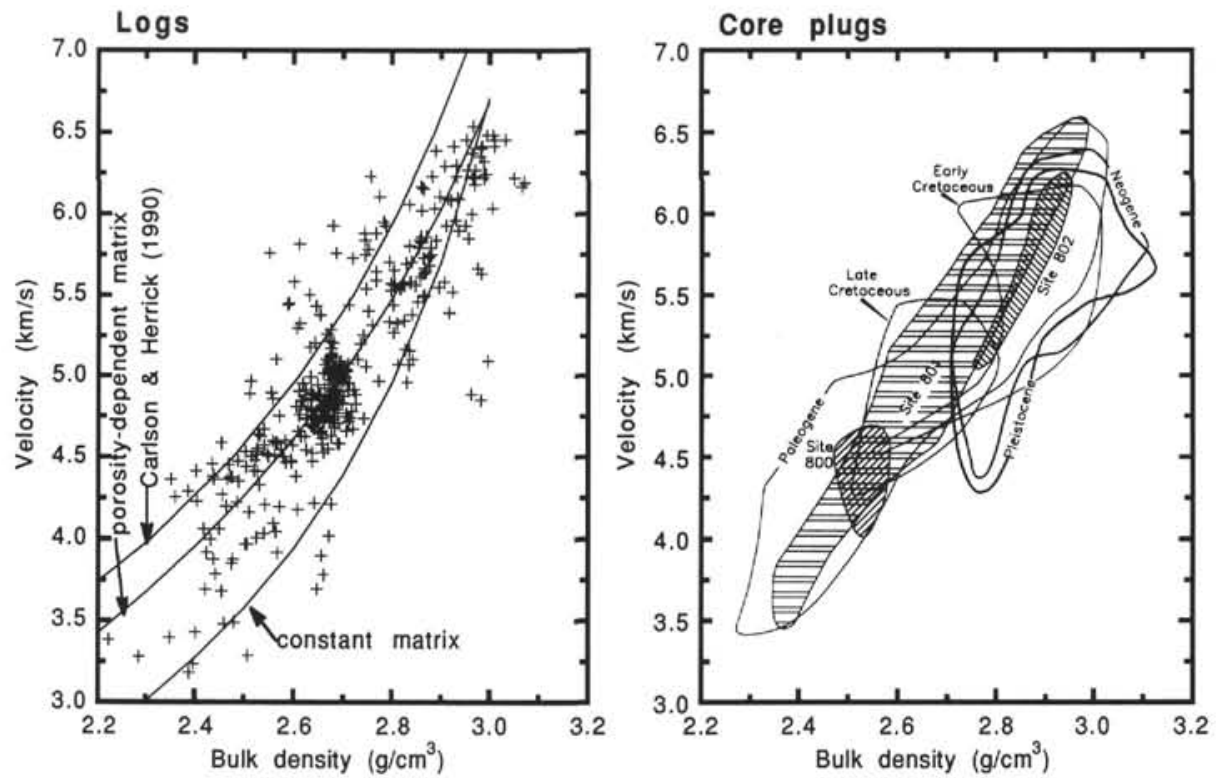

Figure 6. Relationship between velocity and density, based on Site $801 \operatorname{logs}$ (left) and on core-plug measurements from various sites including 801 (right; from Busch et al., 1992). Also shown for comparison to the Site $801 \mathrm{log}$ data are the plug-based preferred model of Carlson and Herrick (1990) and predicted relationships based on the Wyllie et al. (1956) time-average equation and either constant matrix values or porosity-dependent matrix values. Note that porosity-dependent matrix values give the most successful prediction of both the Site $801 \mathrm{log}$ pattern and the core-plug pattern.

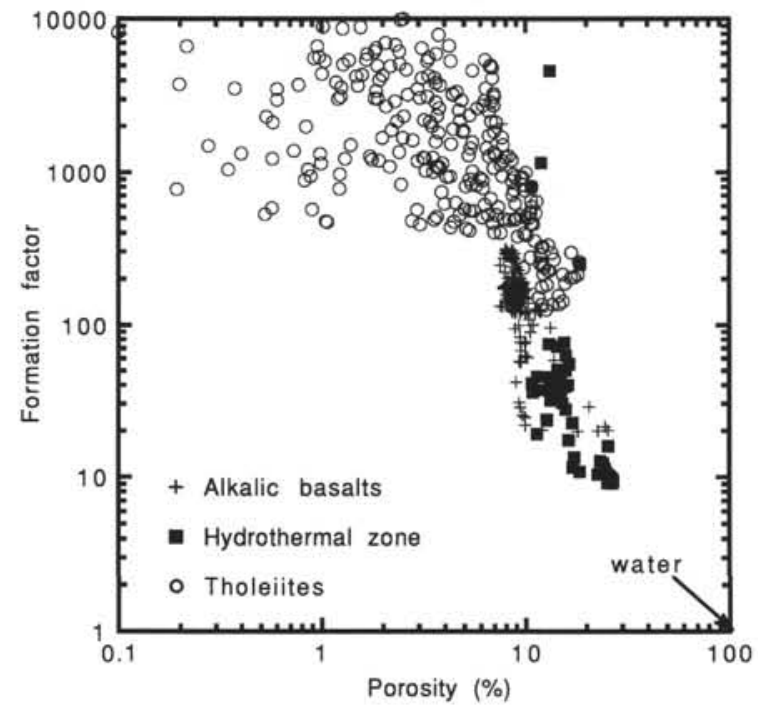

Figure 7. Log-based comparison of formation factor (the ratio of formation resistivity to fluid resistivity) to porosity for Site 801 basalts. Zonation of the three lithostratigraphic units (alkalic basalts, hydrothermal zone, and tholeiites) is shown in Figure 9A.

and that $a<1$. Evaluating the three major lithostratigraphic subdivisions (alkalic basalts, hydrothermal zone, and tholeiitic basalts) separately, however, a different pattern is revealed. For the tholeiites, the highest porosity rocks indicate a linear trend with an intercept $a$ of about 4-10, broadly consistent with results from other sites. In contrast, tholeiites with a calculated porosity of less than $1 \%$ show no apparent correlation of formation factor to porosity, probably because our porosity determination has an error of at least $1 \%$ ( 1 porosity unit, or an error in fractional porosity of 0.01 ). The relationship of formation factor to porosity among the alkalic basalts and hydrothermally altered rocks parallels that among the tholeiites, but is significantly offset downward. This offset may indicate that the alkalic basalts and hydrothermal precipitates do have large components of surface con- duction in addition to their porosity-dependent conductivities. Alternatively, our conversion from bulk density to porosity may be inappropriate for these rocks; assuming higher grain densities would yield higher calculated porosities and remove the anomaly.

\section{NEUTRON POROSITY}

ODP neutron-porosity logs are the least reliable of the four geophysical log types considered in this study. Several studies of DSDP and ODP neutron-porosity logs (Anderson et al., 1985; Broglia and Moos, 1988; Lysne, 1989; Moos, 1990) have found that these logs consistently overestimate the porosity of basalts. Broglia and Ellis (1990) utilized logs from five sites to analyze the relative contributions of several factors to this systematic bias. They concluded that the most important factor is the ODP technique of running the neutron-porosity tool without appropriate eccentralization. At the one site (Site 735) that was logged with a bowspring-eccentralized neutron tool, this bias was absent. Although neutron tools are "compensated" in the sense of applying some correction for tool standoff from the borehole wall, Broglia and Ellis (1990) found that this compensation is insufficient for correction of neutron logs that lack eccentralization.

The neutron $\log$ obtained for the basalts at Site 801 was not run eccentralized. Furthermore, the dramatic hole-size variations are likely to cause some unreliably large porosities. At Site 801, neutron porosities are about $25 \%-35 \%$ in the alkalic basalts, $25 \%-70 \%$ in the hydrothermal zone and adjacent flow units, and 5\%-30\% in the more massive tholeiites (Fig. 8). Comparison to density-based porosity indicates that the neutron tool overestimates porosity in all three types of formation, by $5 \%-25 \%$. This discrepancy is higher than the range of biases detected by Broglia and Ellis (1990) in other ODP crustal sites. The magnitude of neutron-porosity error increases with increasing basalt porosity (Fig. 8).

Neutron logs actually respond primarily to hydrogen content, and porosity is calculated assuming that all hydrogen is in the form of pore water. When clay minerals are present, their bound water causes neutron logs to overestimate porosity, and this effect partly accounts for the discrepancies noted by Broglia and Ellis (1990) and this study. The interval 510-528 mbsf that has the greatest neutron error corresponds to a hydrothermal zone, some of which is composed of a mixture of quartz and iron oxyhydroxide. Hydrogen in the iron oxyhydroxide can 

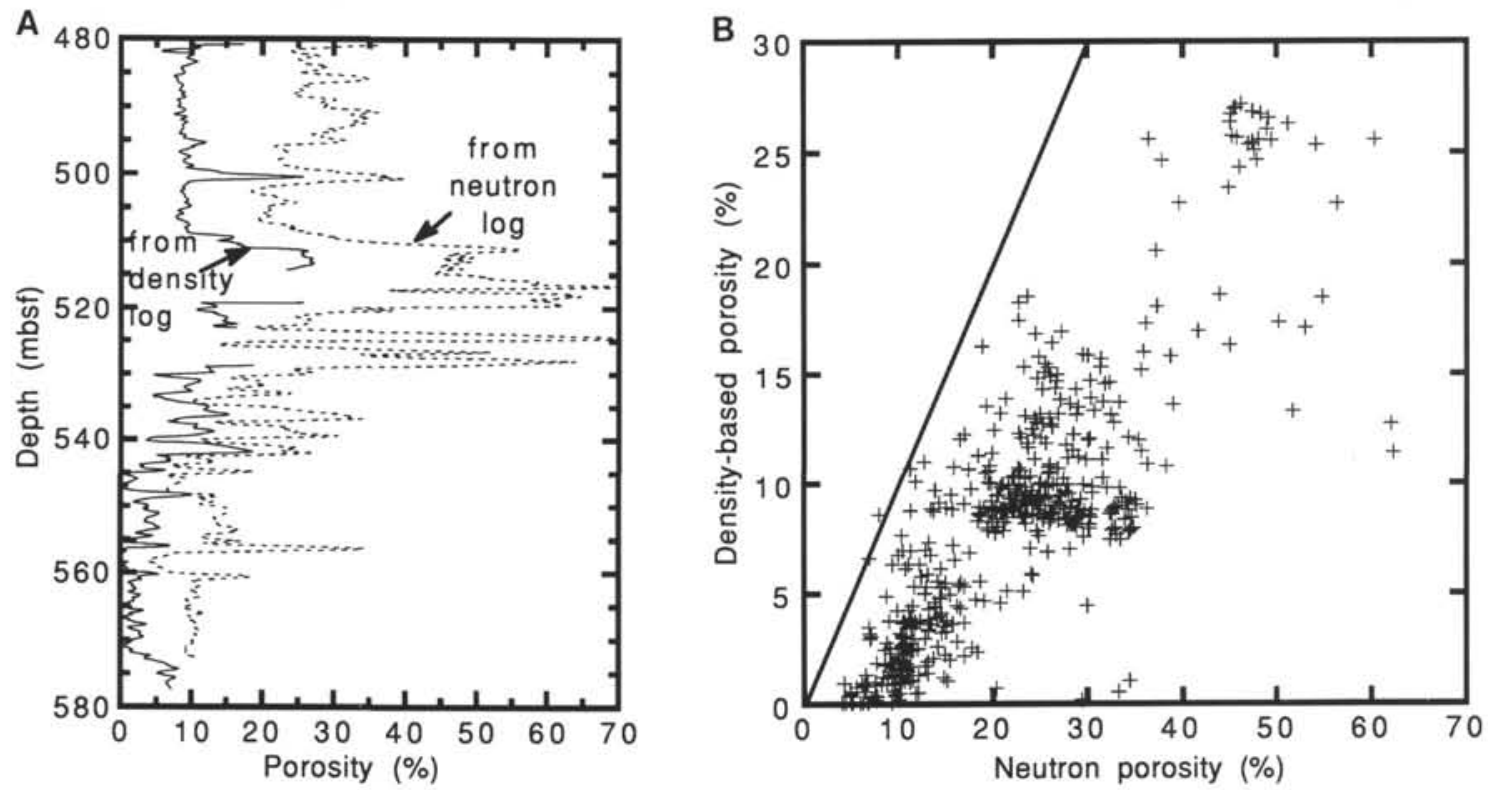

Figure 8. Comparison of density-log and neutron-log porosities, both by $\log / \operatorname{depth}$ plot (A) and crossplot (B). We consider the density porosities to be reliable. Neutron-porosity bias is present throughout the logged interval, and the magnitude of the error increases with increasing porosity.

be expected to cause some neutron bias, but the bias evident in Figure $8 \mathrm{~A}$ is far larger than can be accounted for by this contribution.

\section{FORMATION MICROSCANNER}

Electrical images of the oceanic crust within Hole 801C were collected with the Formation MicroScanner (FMS). The FMS creates an electrical picture of the formation by mapping its electrical conductivity within a few centimeters of the borehole wall. This is accomplished with small, pad-mounted electrodes that are individual transmission points to a common receiver (Ekstrom et al., 1986; Luthi and Banavar, 1988). The configuration developed for ODP uses four orthogonally mounted arrays of 16 electrodes each to determine the variations in formation conductivity. Each of the four electrode arrays maps a section of the borehole wall about $4.5 \mathrm{~cm}$ wide, for a total coverage of about $22 \%$ of a $25-\mathrm{cm}$ diameter borehole $(80 \mathrm{~cm}$ circumference) on each logging run (Molinie and Ogg, 1992).

Because separate electrical signals are transmitted from each of the electrode buttons spaced about $0.25 \mathrm{~cm}$ apart, the FMS images have a vertical resolution on the order of $1-2 \mathrm{~cm}$; this resolution exceeds that of conventional logs by 1-2 orders of magnitude. This very high FMS resolution permits relatively precise location of individual features within the formation, as well as quantification of their sizes and shapes. FMS data are displayed as relative resistivity, coded as gray-scale or color images; in the figures shown here (Fig. 9), white represents the most resistive values and black the least resistive ones. A magnetometer in the FMS tool string normally enables orientation of these images relative to the north magnetic field. Some portions of Hole $801 \mathrm{C}$ have a sufficiently high remanent magnetization, however, to distort this orientation signal; consequently, some apparent orientations in Figure 9 are inaccurate by an unknown amount.

Three FMS logging runs were made in Hole $801 \mathrm{C}$. The first run logged the interval from $574 \mathrm{mbsf}$ (total depth of the hole is $593 \mathrm{mbsf}$ ) up to the casing shoe at 483 mbsf. An interval of narrow hole visible on the caliper of this run apparently bridged over by the time the second FMS run was initiated; the second and third runs only penetrated to an impassible obstruction at $552 \mathrm{mbsf}$. The first, deepest run was of generally poorer quality than the later runs; the caliper for this run suggests that the problem was incomplete opening of the arms, resulting in loss of wall contact for two pads. One of the four pads was consistently noisy throughout this experiment, so we have eliminated those data and only display information from the three remaining pads in our illustrations.

Figure 9 shows samples of the FMS logging results, illustrating how these images more precisely define the formation boundaries and morphology within Hole 801C. Gray-level scaling for each figure is based on the maximum range of resistivities within the interval displayed. Figure 9A shows all of the second logging run (552-483 mbsf), along with one of the FMS caliper logs. This run penetrated the upper $20-30 \mathrm{~m}$ of the tholeiitic basalts, the entire alkalic basalt section, and the intervening hydrothermal unit. In general, the tholeiitic basalts have high resistivities, the alkalic basalts have intermediate resistivities, and the hydrothermal unit has extremely variable and often very low resistivities.

The most obvious characteristic of the tholeiitic and alkalic basalt images is a pervasive horizontal layering. Whereas the horizontal exaggeration of Figure 9A overemphasizes the horizontality of this layering, Figures $9 \mathrm{~B}$ and $9 \mathrm{C}$, which display expanded $10 \mathrm{~m}$ sections of these data, demonstrate that this layering is present on scales from $1 \mathrm{~m}$ down to $0.1 \mathrm{~m}$. Some thin bands of low resistivity are probably cracks; others are preferential alteration along original cooling unit boundaries of sheet flows and thin intrusions. These images are reminiscent of basalt cores recovered from Hole 462A in the nearby Nauru Basin (Shipboard Scientific Party, 1981); those basalts were interpreted to be part of a huge Middle Cretaceous volcanic complex that was extruded and intruded very rapidly over original Jurassic oceanic crust (Batiza et al., 1980). Because the tholeiitic basalts in Hole $801 \mathrm{C}$ were formed at high spreading rates, it is likely that rapid extrusion characterized these basalts as well. At these high rates of basalt emplacement, sheet flows, thin intrusions, and horizontal cooling-unit boundaries seem to dominate over pillow structures (Ballard et al., 1979; Bonatti and Harrison, 1988). The alkalic basalts could have formed by similarly high rates of extrusion and intrusion as off-ridge eruptions 4-14 m.y. later. This interpretation of the horizontal layering in the FMS data is supported by the core samples.

The most distinctive portion of the FMS logs is the hydrothermal zone at 510-528 mbsf (Fig. 9A). Although subtle on Figure 9A, the following stratigraphy is evident on expanded and color-coded FMS displays of the hydrothermal unit:

509.4-510.4 mbsf: transition from high-resistivity to low-resistivity alkalic basalts. 


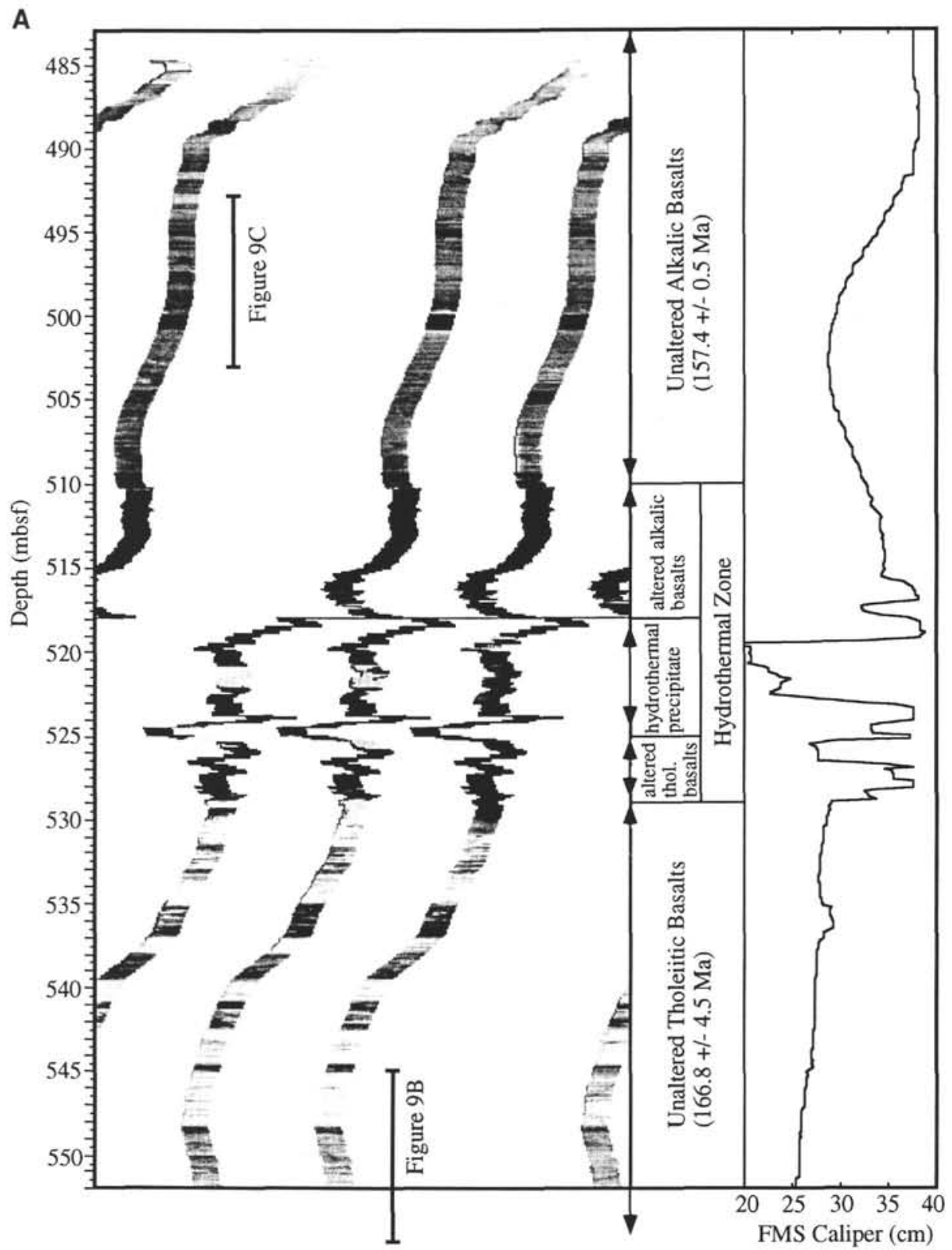

Figure 9. A. FMS imaging of the interval $483-552$ mbsf, along with one of the caliper logs from the same logging run. Relative resistivity is displayed in static format (scaled uniformly across the entire 69-m interval), with white indicating more resistive intervals and black indicating less resistive intervals. Radiometric ages (Pringle, 1992) and lithologic interpretations are also shown. B. Dynamic-format imaging of the interval 545-555 mbsf by the first FMS logging run, along with the vertical component of the magnetometer record from that same run. Three short intervals near 551, 552, and 554 mbsf were eliminated because vertical streaking of the data indicated tool sticking. C. Dynamic-format imaging of the interval 493-503 mbsf by the second FMS logging run, along with a compressional velocity log of that same interval. Also shown are the approximate levels where the packer element was set during the permeability experiment (Larson et al., this volume). Although the $1.5-\mathrm{m}$ length of the packer element is accurately scaled, the depth of the element relative to the FMS records is only accurate to about $1 \mathrm{~m}$.

510.4-518.0 mbsf: iron and silica-rich, hydrothermally altered basalt; horizontal banding is very apparent on detailed inspection.

518.0-525.0 mbsf: iron and silica-rich hydrothermal precipitate, with no apparent banding and with extremely variable resistivity among pads.

$525.0-528.2$ mbsf: iron and silica-rich, hydrothermally altered basalt. Some banding is apparent, but less than in the top hydrothermal zone. Resistivity is relatively uniform among pads.

528.2-528.9 mbsf: transition from low-resistivity to high-resistivity basalts. This transition, which occurs abruptly on all pads, appears to be a contact zone with substantial dip. Its difference in depth among the four pads may, however, result from loss of pad contact by two pads in the sudden washout above the boundary.

The prevalence of horizontal layering in the intervals 510-518 mbsf and 525-529 mbsf leads us to interpret these portions of the hydrothermal zone as altered alkalic and tholeiitic basalts, respectively. We interpret the layered, low resistivities as evidence for more porous and permeable intervals adjacent to the central, lower porosity portion of the hydrothermal precipitate. The interior interval 518-525 mbsf probably consists predominantly of the yellow, iron- and silicarich oxyhydroxide recovered in Core 129-801C-4R.

Figure 9B shows an expanded, 10-m section of FMS data from within the tholeiitic basalt sequence. These data, recorded on the first FMS run, are dynamically gray-scaled based on the resistivity range within this short interval. Thus they cannot be quantitatively compared with the same interval shown in the static display of the second run in Figure 9A. In spite of these differences, the resistivity boundary at $548.5 \mathrm{mbsf}$ is apparent on both figures. This boundary coincides with the boundary between weakly magnetized (above $548.5 \mathrm{mbsf}$ ) 


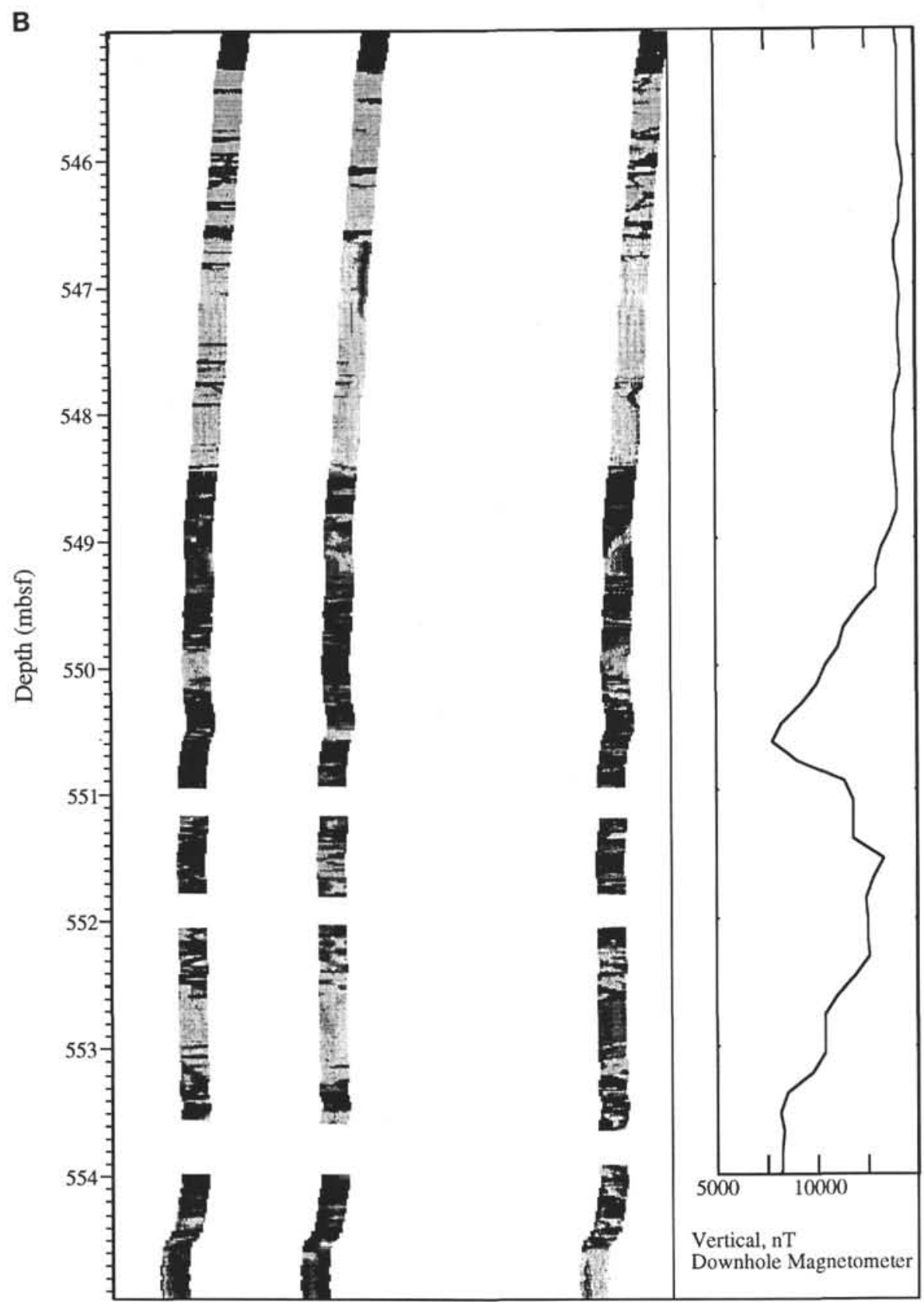

Figure 9 (continued).

and strongly magnetized tholeiitic basalts, as seen in the verticalcomponent magnetometer record (Fig. 9B). The smooth, regional field level (vertical component of $\sim 14,000 \mathrm{nT}$ ) gives way to lower field values produced by negative anomalies below the resistivity boundary. This boundary separates more uniform and more resistive basalts above $548.5 \mathrm{mbsf}$ from more layered and less resistive basalts below. This apparent correlation of magnetic and FMS boundaries may be coincidental, as the tholeiitic basalt sequence seems to be generally subdivided into several resistivity units of this type with overall unit thicknesses on the order of $10 \mathrm{~m}$ (Fig. 9A).

Figure $9 \mathrm{C}$ shows an expanded section from the alkalic basalt sequence. As in Figure 9A, it is apparent that the horizontal to subhorizontal layering carries through in this unit at scales down to $0.1 \mathrm{~m}$. Set among these thin, low-resistivity units is a thicker one from 499.9 to $500.8 \mathrm{mbsf}$ that partially coincided with the approximate level of the packer element during the permeability experiment reported by Larson et al. (this volume). As discussed later, the geophysical and geochemical logs across this bed suggest that it is interflow sediment. Single- trace logs such as the velocity log shown on Figure $9 \mathrm{C}$ suggested that the packer could have been set within a very soft and potentially permeable unit that might have allowed fluid leakage around the packer, invalidating the experiment. Although other hydrologic and mechanical parameters measured during the permeability experiment also suggest that this was not the case, we were relieved to see that the FMS data reveal the soft unit to be $0.9 \mathrm{~m}$ thick, less than the $1.5-\mathrm{m}$ contact length of the packer element. Thus, although the packer may have partially overlapped this soft zone during the permeability experiment, enough packer contact with high-resistivity basalts probably occurred to assure good hydrologic and mechanical seals.

\section{GEOCHEMICAL AGING OF OCEANIC CRUST: EVIDENCE FROM HOLE 801C LOGS}

Is the plug-based correlation between greater alteration and greater porosity also evident in the continuous records available from in situ logs? We investigated this question by comparing core measurements 


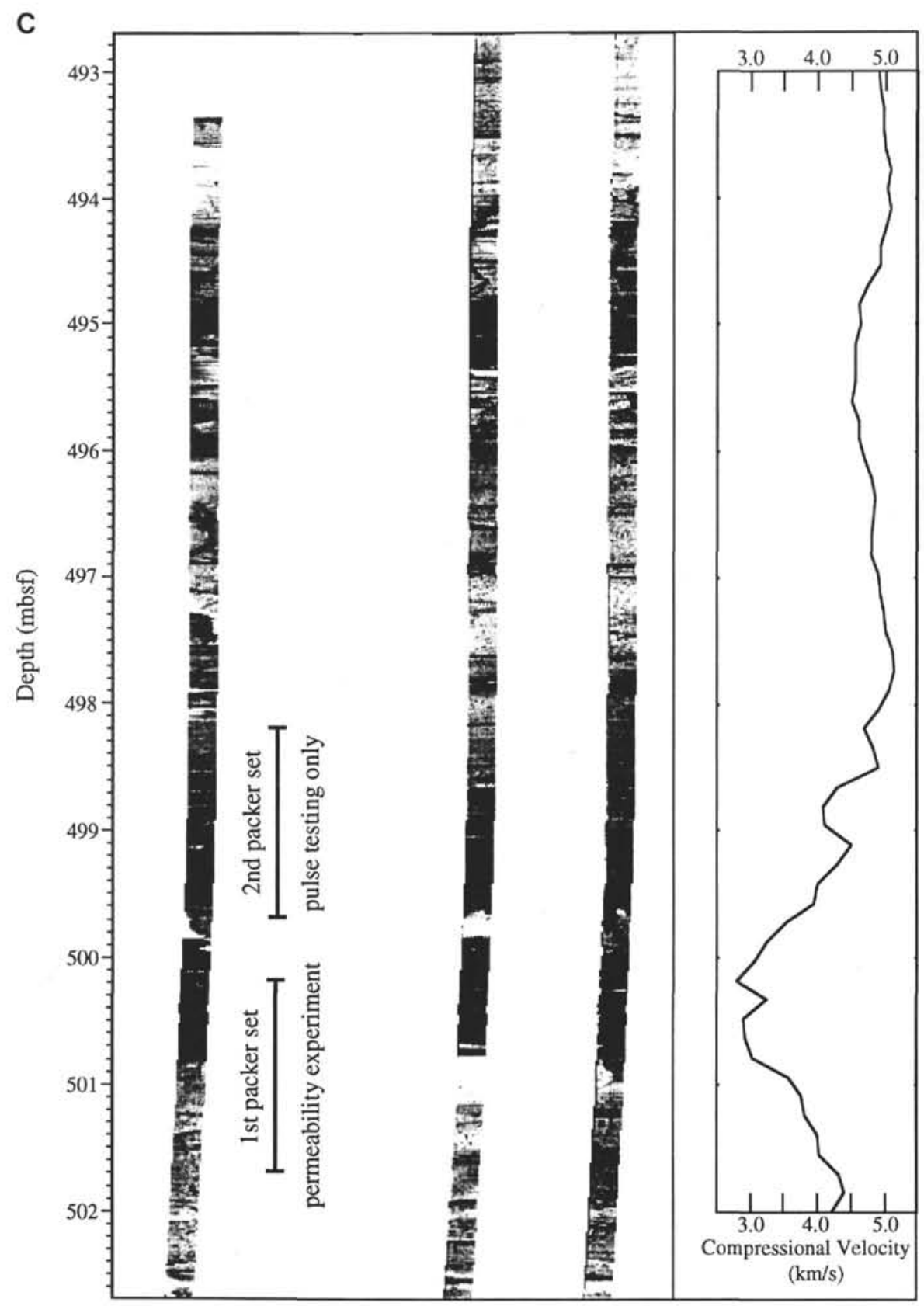

Figure 9 (continued).

of $\mathrm{H}_{2} \mathrm{O}^{+}$, potassium, and porosity to $\log$ measurements of porosity (from Eq. [3]) and potassium (Fig. 3). The $\mathrm{H}_{2} \mathrm{O}^{+}$of basalts, as measured by X-ray fluorescence, does provide a semiquantitative measure of the extent of alteration-induced hydration (Alt et al., 1992).

The potassium content of altered basalts is often an order of magnitude higher than that of fresh basalts because of potassium absorption from seawater during alteration. Consequently, Broglia and Moos (1988) found that both the potassium log and total gammaray $\log$ at Hole $418 \mathrm{~A}$ were highly correlated with qualitative ratings of core alteration and could be used to indicate variation in content of potassium-rich alteration minerals at that site. Low-temperature alteration does not always lead to such a simple correlation; its presence cannot be assumed without direct evidence.

Based on core $\mathrm{H}_{2} \mathrm{O}^{+}$, Hole $801 \mathrm{C}$ tholeiites are less altered than shallower basalt and have little or no alteration-induced $\mathrm{K}$ enrichment. In contrast, the upper alkalic basalts are moderately to highly altered and are $\mathrm{K}$ enriched. Evaluation of $\mathrm{K}$ enrichment in the alkalic basalts is complicated, however, by primary compositional variations. The intervening hydrothermal zone appears to be moderately to highly altered and $\mathrm{K}$ poor, based on a single-core measurement, but core descriptions indicate that this deposit has been completely transformed to a mixture of quartz and iron oxyhydroxide (Alt et al., 1992). The unit is flanked by thin, K-rich zones, based on the $\mathrm{K}$ log.

This broad zonation of alteration is accompanied by a consistent porosity zonation (Fig. 3): the lower tholeiites are lowest in porosity and least altered, the upper alkalic basalts are intermediate in porosity and alteration, and the intervening hydrothermal zone is heterogeneous and often very high in both porosity and alteration. Porosity and $\mathrm{K}$ enrichments are not, however, simply correlated (Fig. 3), probably because both $\mathrm{K}$-rich and $\mathrm{K}$-poor alteration minerals were formed (Alt et al., 1992).

Other geochemical logs (Fig. 10) confirm the division of these basalts into three lithologic units: upper alkalic basalts, middle hydrothermal zone, and lower tholeiites. These logs demonstrate that the 
hydrothermal zone is $18 \mathrm{~m}$ thick (510-528 mbsf), much thicker than the $3 \mathrm{~m}$ of iron oxyhydroxide recovered in coring (Shipboard Scientific Party, 1990b). This hydrothermal zone is geochemically somewhat heterogeneous, but it is consistently much higher in silicon and much lower in aluminum (Fig. 10) than any basalts. Log responses suggest that the entire $18-\mathrm{m}$ interval is geochemically similar to the single core geochemical analysis, so the entire interval could be iron oxyhydroxide. Sparse core recovery (e.g., Core 144-801C-3R) and the continuous FMS images suggest, however, that only the central portion of this zone is hydrothermal precipitate.

The porosity of this hydrothermal zone is extremely variable: a 4-m-thick, low-porosity zone ( $519-523 \mathrm{mbsf})$ is flanked by much higher porosities in the remainder of the unit. This porosity zonation is seen most reliably in the resistivity (Shipboard Scientific Party, 1990b) and FMS (Fig. 9A) logs; it is also evident in the velocity (Fig. 1), density (Fig. 1), and neutron porosity (Fig. 8) logs, but the extremely variable hole size may affect the quality of those logs in the interval 515-529 mbsf. Probably, coring has preferentially recovered nearly all of the low-porosity part of the hydrothermal deposit but washed away more porous zones.

A single spike is evident on most geochemical logs at $501 \mathrm{mbsf}$, within the alkalic basalts. Based on its very high $\mathrm{SiO}_{2}$ and very low $\mathrm{Al}_{2} \mathrm{O}_{3}$ and $\mathrm{TiO}_{2}$, it is more likely to be sedimentary than basaltic. This thin bed is also very low in velocity, density, and resistivity, and it corresponds to the "soft spot" imaged by FMS and previously discussed. A small amount of sediment was recovered from the core that bracketed this depth at Hole 801B (Shipboard Scientific Party, 1990b); none was recovered at Hole $801 \mathrm{C}$.

The geochemical logs (Fig. 10) clearly detect the higher potassium and titanium of alkalic basalts compared to tholeiites. They indicate, however, that the tholeiites are lower in aluminum than the alkalic basalts; core measurements confirm that this pattern is valid in general, but not for the geochemically logged portion of tholeiite. Core measurements show that calcium and iron are consistently higher in the tholeiites than in the alkalic basalts. Although the $\mathrm{CaO}$ and $\mathrm{FeO}$ geochemical logs suggest the same pattern, the difference is largely obscured by the much greater variability of these log measurements than of core measurements.

Geochemical logs respond not only to basalt chemical composition-both primary and alteration-induced-but also to alteration minerals in fractures and interpillow voids that are missed by coring. Calcium and potassium, in particular, can be higher at the interflow scale sampled by logs than at the intergranular scale of core plugs, as a result of the concentration of these elements as crack-filling calcite and clay alteration minerals. Figure 11 examines this possibility, through $\mathrm{CaO}$ vs. $\mathrm{K}_{2} \mathrm{O}$ crossplots. Core analyses (Castillo et al., 1992) indicate that the original compositional difference between tholeiite and alkalic basalt (higher $\mathrm{CaO}$ and much lower $\mathrm{K}_{2} \mathrm{O}$ in the tholeiites) is modified by alteration, causing occasional $\mathrm{CaO}$ depletion and $\mathrm{K}_{2} \mathrm{O}$ enrichment in both (Fig. 11). This pattern could be expected to be modified at the interflow scale, with occasional very high $\mathrm{CaO}$ values indicative of calcite precipitation.

The $\mathrm{CaO}$ vs. $\mathrm{K}_{2} \mathrm{O}$ pattern observed in geochemical logs is quite different from that in cores. First, no evidence of an alteration-induced inverse correlation between $\mathrm{CaO}$ and $\mathrm{K}_{2} \mathrm{O}$ is observed in the log data. Second, although the mean log-based $\mathrm{CaO}$ concentration agrees with cores for both tholeiites and alkalic basalts, the variance is much higher in the logs. Many samples even have an apparent $\mathrm{CaO}$ concentration of zero, far less than the most severe depletion would induce. The combination of these two observations strongly suggests that the $\mathrm{CaO}$ $\log$ has a very high noise level; its usefulness for detecting either primary or secondary chemical variations is minimal. The very high variability of the $\mathrm{FeO} \log$ (Pratson et al., this volume), not shown here, is similarly greater than can be attributed to basalt alteration.

Alt et al. (1992) showed that a crossplot of $\mathrm{K}_{2} \mathrm{O}$ vs. $\mathrm{H}_{2} \mathrm{O}^{+}$is a moderately successful alteration indicator in the Site 801 basalts; primary compositional variations among the alkalic basalts and potassium-free alteration minerals degrade the relationship. The $\mathrm{Th} / \mathrm{K}_{2} \mathrm{O}$ ratio (Fig. 12) appears to be superior to total potassium in detecting alterationinduced potassium enrichment among the tholeiites; it too may be nondiagnostic among the alkalic basalts. Figure 12 also shows both core and $\log \mathrm{Th} / \mathrm{K}_{2} \mathrm{O}$ ratios as a function of depth. Within the tholeitic basalts, the log-based ratios are likely to be a good indicator of largescale alteration, with lowest $\mathrm{Th} / \mathrm{K}_{2} \mathrm{O}$ corresponding to most altered zones. Comparison of this log to the porosity (Fig. 3) and velocity (Fig. 1) logs appears to indicate that greater alteration is correlated with both greater porosity and lower velocity. This pattern, already observed at the plug scale, is therefore extended to the much larger log scale.

\section{CRUSTAL STRUCTURE}

How do the average velocity, density, and porosity measurements that we have obtained for Hole $801 \mathrm{C}$ compare with those determined at other sites? To answer this question, we must consider the properties of Hole $801 \mathrm{C}$ and of other sites in the context of concepts of crustal evolution.

Carlson and Herrick (1990) provide a comprehensive synthesis of the variations of oceanic crustal velocity, density, and porosity with depth and age. Based primarily on geophysical logs from Holes $395 \mathrm{~A}$ $(6 \mathrm{Ma})$ and $418 \mathrm{~A}(110 \mathrm{Ma})$, layer $2 \mathrm{a}$ has a velocity of $3.7 \pm 0.4 \mathrm{~km} / \mathrm{s}$, a density of $<2.3 \mathrm{~g} / \mathrm{cm}^{3}$, and a porosity of about $30 \%$. Layer $2 \mathrm{~b}$ has a velocity of $5.2 \mathrm{~km} / \mathrm{s}$, a density of $2.62-2.69 \mathrm{~g} / \mathrm{cm}^{3}$, and a porosity of $10 \%$. Sonobuoys indicate that layer $2 \mathrm{a}$, with an average thickness of about $0.7-1.5 \mathrm{~km}$ for crust $<5 \mathrm{Ma}$, thins gradually with increasing age and may be absent from crust $>40 \mathrm{Ma}$ (Houtz and Ewing, 1976). Logging results at all crustal sites have shown that the layer models of sonobuoys are conceptual oversimplifications; gradual transitions from layer $2 \mathrm{a}$ to layer $2 \mathrm{~b}$ properties were observed. Furthermore, neither the logs nor the standard model for crustal evolution indicates a simple thinning of layer $2 \mathrm{a}$ with time. Instead, porosity is thought to decrease simultaneously throughout the uppermost basaltic crust as a result of the precipitation of alteration minerals (clays, zeolites, and calcite); velocity and density, therefore, increase (e.g., Broglia and Moos, 1988).

The standard model for crustal aging (Fig. 13), in conjunction with syntheses such as that of Carlson and Herrick (1990), makes predictions concerning the velocity, density, and porosity of the upper crust at ODP sites. However, seismic models (Kennett and Orcutt, 1976; Purdy, 1983; Vera and Mutter, 1988) show large velocity gradients in the top $2 \mathrm{~km}$ of oceanic crust, so the predicted averages are probably too high for velocity in the top 100-200 m of crust. DSDP and ODP holes provide a partial picture of the change in oceanic crustal properties with age (Moos et al., 1990; Carlson and Herrick, 1990; Jarrard and Broglia, 1991; Shipboard Scientific Party, 1990a). Layer 2a is 100-175 m thick at Hole 504B (6 Ma), approximately $250 \mathrm{~m}$ thick at Hole 395 A (7 Ma), at least $200 \mathrm{~m}$ thick at Hole $768 \mathrm{C}(18 \mathrm{Ma})$, and absent at Holes $770 \mathrm{C}$ (42 Ma), 418A (110 Ma), and 765D (125-130 Ma).

At Hole $801 \mathrm{C}(167 \pm 4 \mathrm{Ma})$, velocities in the upper alkalic-basalt and lower tholeiite intervals are $4.7-6.4 \mathrm{~km} / \mathrm{s}$ (Fig. 1), consistent with layer $2 \mathrm{~b}$ and even layer $2 \mathrm{c}$ velocities, but inconsistent with layer $2 \mathrm{a}$ velocities. In contrast, the hydrothermal zone appears to have velocities as slow as, or slower than, those in layer $2 \mathrm{a}$. Because of the short tholeiitic-basalt penetration, however, we consider this agreement with the velocity/age model to provide only a weak confirmation of that model. Crustal heterogeneity may be too high for the crustalaging model to provide useful velocity predictions for crustal samples of 100-200 m at individual sites. For example, Jarrard and Broglia (1991) found that Sites 768 and 770 also had velocities consistent with those predicted on the basis of their age, yet Site 770 has more "evolved" (faster, more dense, less porous) physical properties, not because of greater age and alteration, but because of lower initial porosity. The same qualifiers apply to a comparison of Site 801 to crustal velocity models: the $131-\mathrm{m}$ basement penetration (and even shorter tholeiite penetration) may be nonrepresentative, and the high 


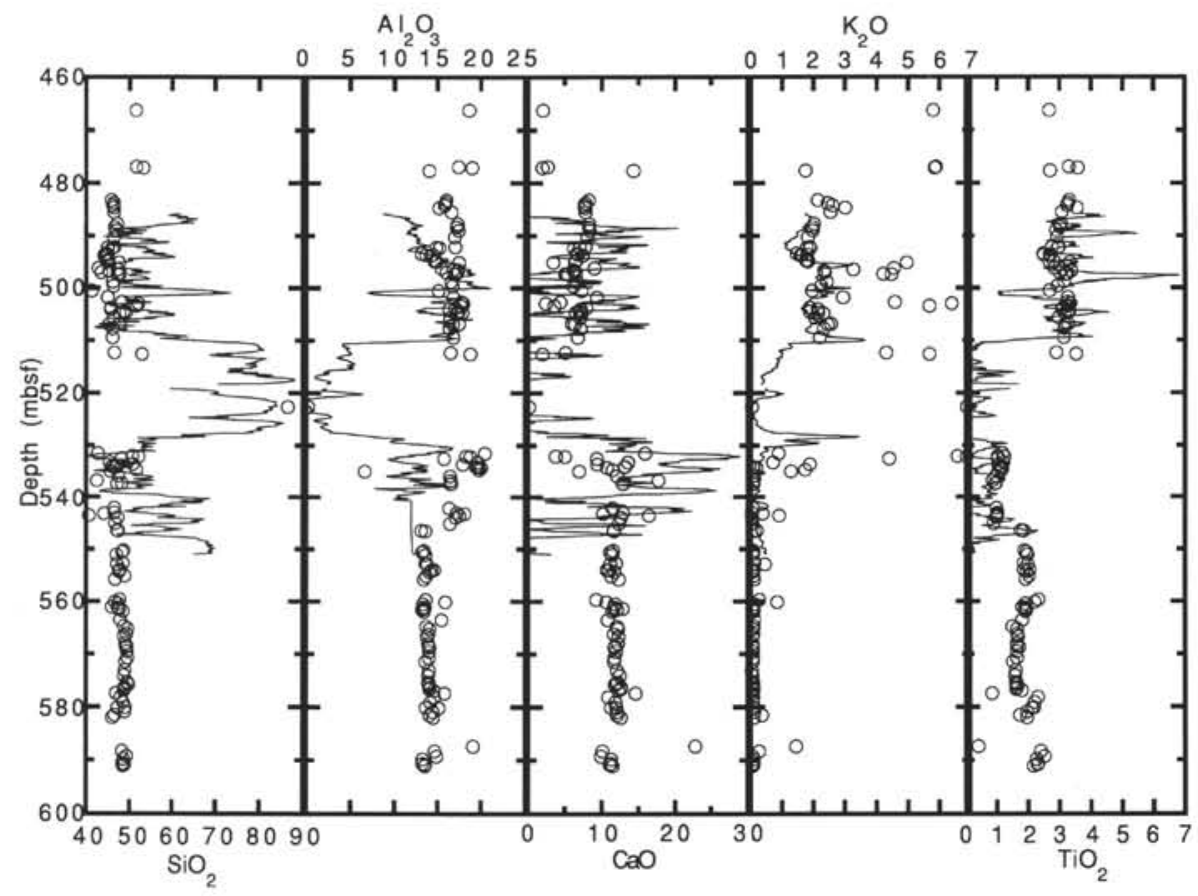

Figure 10. Some geochemical logs for Site 801 basalts (Pratson et al., this volume), as compared with core-plug analyses (circles) compiled by Castillo et al. (1992).

tholeiite and alkalic-basalt velocities may owe more to their flow origins than to subsequent alteration.

\section{GEOPHYSICAL AGING OF OCEANIC CRUST AT HOLE 801C}

According to a standard conceptual model, aging of oceanic crust begins as soon as crust is created. The combination of axial heat and highly fractured, permeable basalt promotes vigorous hydrothermal circulation, which causes crustal alteration. Alteration minerals eventually fill cracks and interpillow voids, thereby reducing porosity and permeability (top flowchart of Fig. 13). This model suggests that hydrothermal circulation is ultimately self-limiting.

Hydrothermal convection through the seafloor is not restricted to the crust and sediments immediately adjacent to spreading centers, but continues within ridge flanks covered by sediments for at least tens of millions of years (e.g., Anderson et al., 1977; Fisher et al., 1990; and many others). Off-axis waning of hydrothermal circulation is caused by decrease in crustal heat, accumulation of a relatively low-permeability sediment cover, and decrease in crustal permeability resulting from alteration. Off axis, sedimentation slows and changes the style of the hydrothermal circulation, from largely low-T with seafloor communication to high- $\mathrm{T}$ when the circulation is isolated from seawater. Of these three mechanisms by which hydrothermal circulation is reduced with time and distance from the ridge, crustal alteration has received the most attention, perhaps because only it can account for the age-dependence of upper crustal velocities (Schreiber and Fox, 1976, 1977).

Of the many changes associated with crustal aging, most are assumed to occur rather than to be directly observable (middle flowchart in Fig. 13). Close to the ridge crest, for example, alteration becomes more pervasive and extreme with increasing crustal age, and Hole 504B provides direct evidence for alteration-induced permeability reduction (Anderson and Zoback, 1982; Anderson et al., 1985; Becker, 1989). We have little direct evidence, however, that fracture filling and porosity reduction are the dominant effects of basalt alteration, nor that greater age leads to steadily decreasing permeability. Indeed, packer experiments at Hole $801 \mathrm{C}$ provided the first test of the assumption that old crust is lower in permeability than young crust, a test that instead found some of the highest crustal permeability ever observed (Larson et al., this volume).

The correlation between greater alteration and greater velocity, assumed to be present at the multiflow scale, is not necessarily observed at the plug scale. Christensen and Salisbury (1972) first observed that core samples typically exhibited the opposite pattern: a velocity decrease associated with increasing alteration and increasing crustal age. Low-temperature alteration breaks down basalt minerals and replaces them with smectites that are lower in matrix velocity and density. Potassium, sodium, and water are absorbed from seawater; calcium silicon, and iron are given off, and the net geochemical flux is out of the basalt (e.g., Hart, 1973), thereby increasing porosity at an intergranular scale.

Velocity and density measurements on Site 801 basalt plugs (Busch et al., 1992) also exhibit this pattern (Fig. 4; bottom flowchart of Fig. 13). Thus, basalt alteration may reduce porosity by fracture filling, but it also increases intergranular porosity. Conversely, high porosity promotes alteration, by providing permeability that assures high volume of circulating fluids; thus the double-headed arrow on Figure 4 relating greater alteration to greater porosity. Using $\mathrm{H}_{2} \mathrm{O}^{+}$from geochemical analyses (Castillo et al., 1992) as a semiquantitative indicator of alteration (Alt et al., 1992), we can see that greater alteration is associated with greater porosity (Fig. 4). Furthermore, alteration reduces matrix velocities and matrix densities by up to $10 \%$. Both matrix-mineral properties and porosity affect velocity and density, and the bottom portions of Figure 4 illustrate this combined effect: velocity and density drop dramatically with greater porosity. Most, but not all, of this drop is predicted by the relations shown by the constant-matrix-value dashed lines. The velocity and density drops with greater porosity are even greater than predicted by the dashed lines, however, because matrix properties also change with greater porosity.

Busch et al. (1992) did not address the conflict between Site 801 plug patterns and the standard model, except to say, "the extent to which [the standard model] is applicable to the laboratory data for the Leg 129 basalts is questionable." Although plugs do reveal intergranular patterns, coring misses cracks and crack-filling that potentially control macroporosity and large-scale velocity (Hyndman and Drury, 1976). Log analysis, in contrast, allows us to determine whether the lab-sample-scale observations also hold at the interflow scale. 

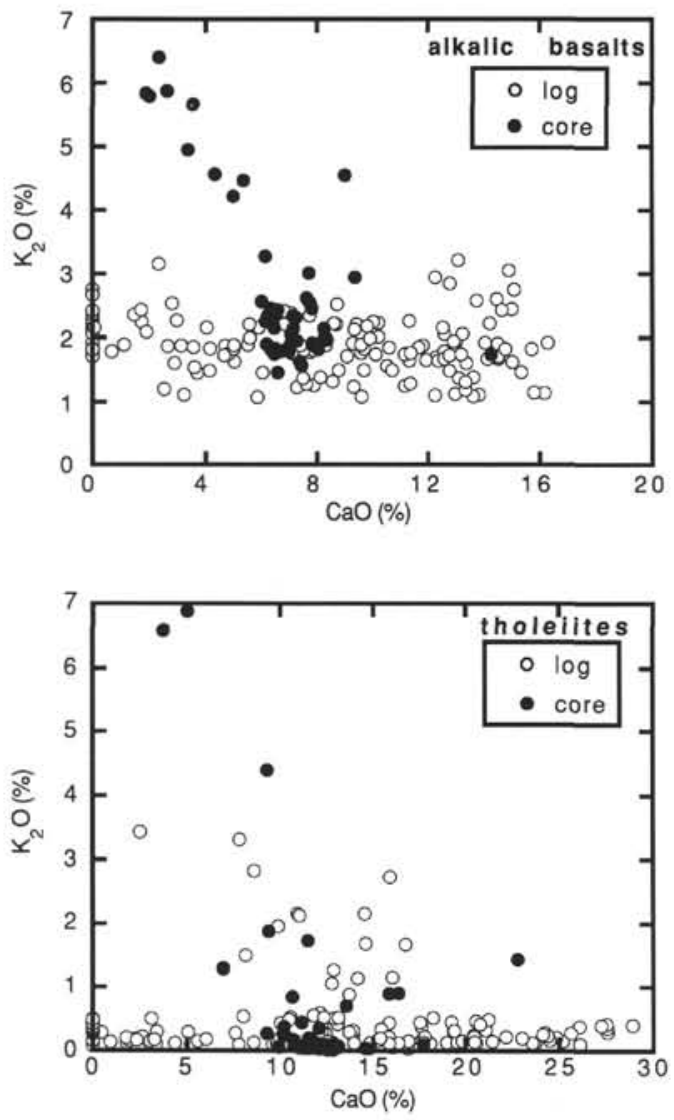

Figure 11. Crossplots of $\mathrm{K}_{2} \mathrm{O}$ vs. $\mathrm{CaO}$, for tholeiites and alkalic basalts, based on core-plug analyses (Castillo et al., 1992) and logs.

Our comparison of log velocity to porosity, for example, found a pattern (Fig. 5) that agreed well with core data. Similarly, the relationship of log density to velocity can be accounted for only by porositydependent matrix values, as seen at the intergranular scale (Fig. 4). Geochemical logs (Fig. 10) confirmed that greatest alteration is correlated with highest porosities and lowest velocities, opposite to the pattern implied by the standard model of Figure 13. If the plug-based relation of greater alteration inducing lower velocity is competing with a flow-scale pattern of alteration-induced crack filling and velocity increase, then the former appears to be dominant both in cores and logs.

On the core-plug synthesis of Busch et al. (1992), note that Pleistocene and Neogene sites differ from other sites (Fig. 6); increasing crustal age is accompanied by increasing alteration, and associated movement of points to lower velocity and density. This pattern for intergranular velocity and density contrasts with the conclusion from sonobuoys that old crust has higher velocities than young crust. The plug-scale velocities of $4.4-6.4 \mathrm{~km} / \mathrm{s}$ for young basalts, if combined with macroporosity in young crust, is compatible with layer $2 \mathrm{a}$ velocities of $3.7 \pm 0.4 \mathrm{~km} / \mathrm{s}$. The plug-scale velocities of $3.5-6.6 \mathrm{~km} / \mathrm{s}$ for older basalts are incompatible with layer $2 \mathrm{~b}$ velocities of $5.2 \pm$ $0.4 \mathrm{~km} / \mathrm{s}$, however, unless the macroporosity of old oceanic crust is negligible.

If much of the porosity in the rare pillow basalts and abundant flows at Hole $801 \mathrm{C}$ is in the form of large-scale voids and fractures that are not sampled by $10-\mathrm{cm}^{3}$ core plugs, then comparison of core and log measurements of velocity or density has the potential of detecting this macroporosity. In such comparisons, however, considerable caution is required because core sampling may not be representative of average formation properties. Core recovery in the basalts averaged $31 \%$ at Hole $801 \mathrm{~B}$ and $60 \%$ at Hole $801 \mathrm{C}$, and the coring process tends to bias basalt core recovery toward fresher, less-altered basalts. Rebound, the
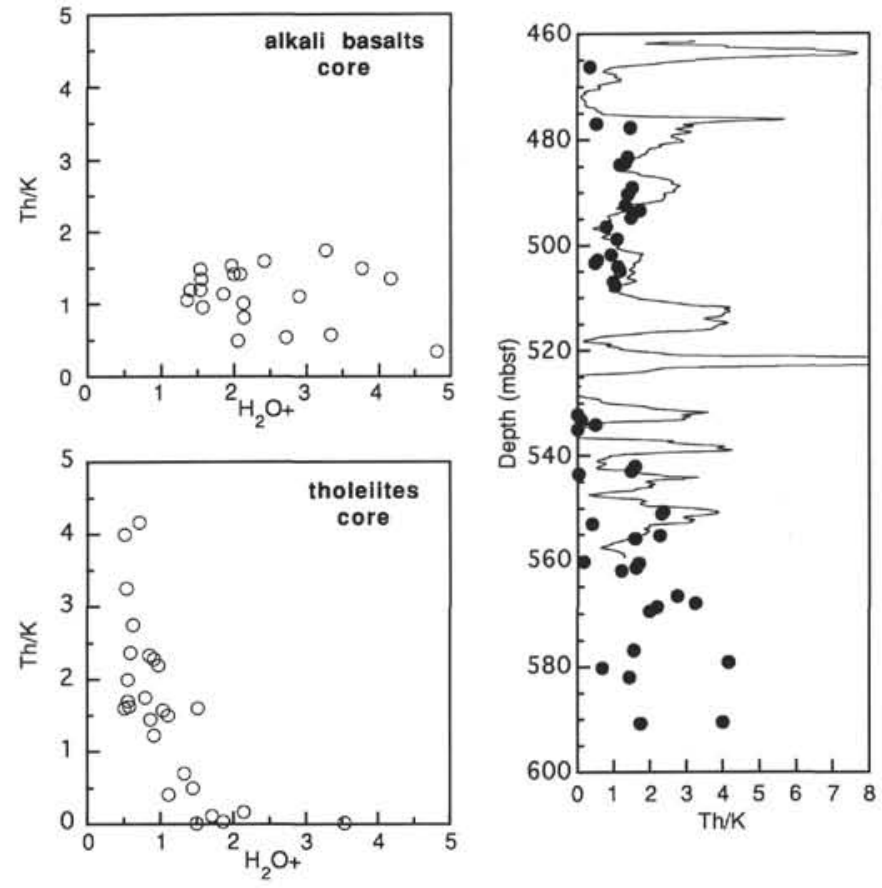

Figure 12. Plots of the thorium/potassium ratio vs. $\mathrm{H}_{2} \mathrm{O}^{+}$and depth. Open circles and solid ovals are core-plug analyses (Castillo et al., 1992); curved line is from the spectral-gamma-ray logging tool. Note that $\mathrm{Th} / \mathrm{K}$ appears to be indicative of degree of alteration (as indicated by $\mathrm{H}_{2} \mathrm{O}^{+}$) within the tholeiites, so the $\mathrm{Th} / \mathrm{K} \log$ for the tholeiite interval (below $528 \mathrm{mbsf}$ ) is a proxy $\log$ of alteration.

core expansion that accompanies change from in-situ to laboratory pressures, can affect densities slightly and plug velocities more substantially (Hamilton, 1976). Rebound is small in these basalts: on the order of a few percent based on measurements of velocity as a function of pressure (Wallick et al., 1992).

In general, the combination of these factors leads one to expect log velocities and densities to be consistent with or slightly lower than core measurements in massive units, and significantly lower than core data in pillows. Instead, the two types of measurement in Hole 801C are generally similar in both the moderate-velocity, moderate-density alkalic basalts and the high-velocity, high-density tholeiites (Fig. 1). Thus this comparison reveals no evidence in these two intervals for large-scale open porosity that has been missed by the plugs. We cannot say whether this absence results from alteration-induced crack fillings or from initial paucity of macroporosity; pillow basalts (and associated interpillow porosity) are very rare at this site. Only in the hydrothermal zone, where plug data are virtually absent and where apparent $\log$ velocities comparable to layer $2 \mathrm{a}$ velocities are not trustworthy, is macroporosity possible. Consequently, the very high permeability measured for the site (Larson et al., this volume) probably is confined to this hydrothermal zone.

This pattern differs from that seen at several younger sites (Kirkpatrick, 1978; Moos et al., 1990; Jarrard and Broglia, 1991), where macroporosity missed by the plugs causes lower velocity and density values for logs. For old sites, in contrast, agreement between plug and log velocities is predicted by the standard model; this prediction is confirmed at Hole 765D (Shipboard Scientific Party, 1990a), refuted at Hole 417D (Salisbury et al., 1980), dominantly refuted at Hole 418A (Moos et al., 1990), and-as shown by Figure 1-confirmed at Hole 801C.

\section{CONCLUSION}

How representative is Hole $801 \mathrm{C}$ of the geophysical properties of very old crust? Certainly the cap of alkalic basalts is atypical of 


\section{A \\ Standard model for aging of oceanic crust:}

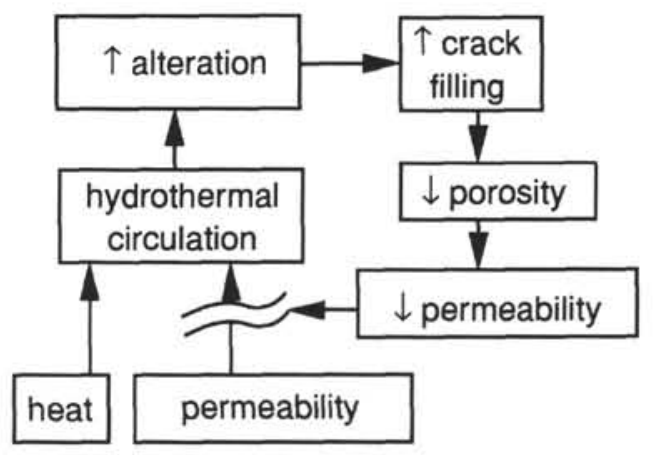

B Expected pattern (at multiflow scale):
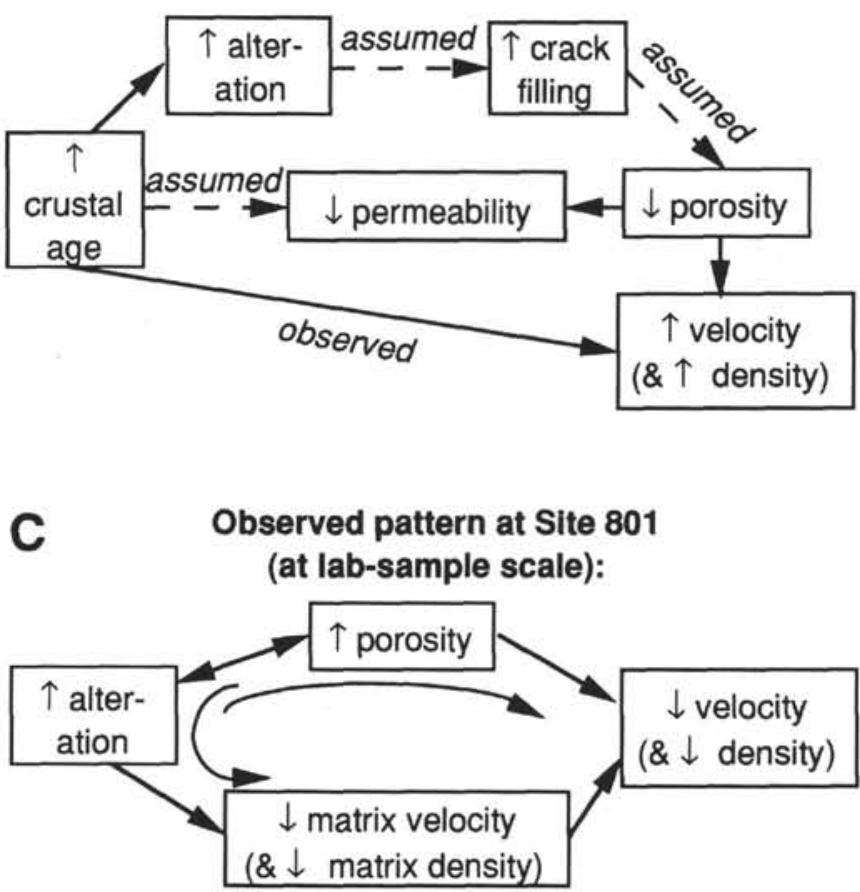

Figure 13. Flowcharts of the interrelations among hydrologic, geochemical. and geophysical parameters during the aging and alteration of oceanic crust. A. Generally accepted "standard model." B. Expected relationships at intraflow and interflow scales, based on the standard model; some links have been verified by observation, whereas others are only assumed. C. Observed pattern at Site 801, based on core-plug measurements. Note the contrast between the multiflow expectation that greater alteration increases velocities and the plug-scale observation of the opposite effect of alteration on velocity.

oceanic crust in general, although it is pervasive in the northwestern Pacific Ocean. Except in the hydrothermal zone, the average upper crustal velocities observed at Hole $801 \mathrm{C}$ are typical of layer $2 \mathrm{~b}$, as expected for very old crust. In the competition between intergranularscale porosity increase and large-scale porosity decrease caused by alteration, Hole $801 \mathrm{C}$ may represent an extreme case. Intergranularscale effects appear to dominate both plug and log measurements here, not because of a lack of large-scale cementation, but because initial volcanic style was in the form of massive flows rather than porous pillows. The most dramatic alteration event at this site was not cementation of macroporosity, but formation of the hydrothermal deposit and associated porosity increase.

\section{ACKNOWLEDGMENTS}

We thank Schlumberger Logging Engineer Steven Kittredge for his excellent operation and maintenance of the logging systems on board Leg 144, and we thank Cristina Broglia, Beth Pratson, and Debbie Barnes at Lamont-Doherty's Borehole Research Group for insightful computer support. We also thank the Co-Chief Scientists and the Shipboard Scientific Party of Leg 144 for the ship time and forbearance, respectively, that allowed us to conduct logging and permeability experiments in Hole $801 \mathrm{C}$ on a leg primarily dedicated to completely different objectives.

This project was made possible by the U.S. Science Support Program. The U.S. Science Program associated with the Ocean Drilling Program is sponsored by the National Science Foundation and the Joint Oceanographic Institutions, Inc. Any opinions, findings, and conclusions expressed in this publication are those of the authors and do not necessarily reflect the views of the National Science Foundation, the Joint Oceanographic Institutions, Inc., or Texas A\&M University.

\section{REFERENCES*}

Abrams, L.J., Larson, R.L., Shipley, T.H., and Lancelot, Y., 1992. The seismic stratigraphy and sedimentary history of the East Mariana and Pigafetta basins of the western Pacific. In Larson, R.L., Lancelot, Y., et al., Proc. ODP, Sci. Results, 129: College Station, TX (Ocean Drilling Program), 551-569.

Alt, J.C., France-Lanord, C., Floyd, P.A., Castillo, P., and Galy, A., 1992. Low-temperature hydrothermal alteration of Jurassic ocean crust, Site 801. In Larson, R.L., Lancelot, Y., et al., Proc. ODP, Sci. Results, 129: College Station, TX (Ocean Drilling Program), 415-427.

Anderson, R.N., Langseth, M.G., and Sclater, J.G., 1977. The mechanisms of heat transfer through the floor of the Indian Ocean. J. Geophys. Res., 82:3391-3409.

Anderson, R.N., O'Malley, H., and Newmark, R.L., 1985. Use of geophysical logs for quantitative determination of fracturing, alteration, and lithostratigraphy in the upper oceanic crust, DSDP Holes 504B and 556. In Anderson, R.N., Honnorez, J., et al., 1985. Init. Repts. DSDP, 83: Washington (U.S. Govt. Printing Office), 443-478.

Anderson, R.N., and Zoback, M.D., 1982. Permeability, underpressures, and convection in the oceanic crust near the Costa Rica Rift, eastern equatorial Pacific. J. Geophys. Res., 87:2860-2868.

Archie, G.E., 1942. The electrical resistivity log as an aid in determining some reservoir characteristics. J. Pet. Tech., 5:1-8.

Ballard, R.D., Holcomb, R.T., and van Andel, T.J.H., 1979. The Galapagos Rift at $86^{\circ} \mathrm{W}, 3$, sheet flows, collapse pits, and lava lakes of the rift valley. J. Geophys. Res., 84:5407-5422.

Batiza, R., Larson, R.L., Schlanger, S.O., Shcheka, S.A., and Tokuyama, H., 1980. Trace element abundances in basalts of the Nauru Basin (DSDPLeg 61): Late Cretaceous off-ridge volcanism in the western Pacific. Nature, 286:476-478.

Becker, K., 1989. Measurements of the permeability of the sheeted dikes in Hole 504B, ODP Leg 111. In Becker, K., Sakai, H., et al., Proc. ODP, Sci. Results, 111: College Station, TX (Ocean Drilling Program), 317-325.

Bonatti, E., and Harrison, C.G.A., 1988. Eruption styles of basalt in oceanic spreading ridges and seamounts: effect of magma temperature and viscosity. J. Geophys. Res., 93:2967-2980.

Broglia, C., and Ellis, D., 1990. Effect of alteration, formation absorption, and standoff on the response of the thermal neutron porosity $\log$ in gabbros and basalts: examples from Deep Sea Drilling Project-Ocean Drilling Program sites. J. Geophys. Res., 95:9171-9188.

Broglia, C., and Moos, D., 1988. In-situ structure and properties of 110-Ma crust from geophysical logs in DSDP Hole 418A. In Salisbury, M.H., Scott,

\footnotetext{
- Abbreviations for names of organizations and publications in ODP reference lists follow the style given in Chemical Abstracts Service Source Index (published by American Chemical Society).
} 
J.H., et al., Proc. ODP, Sci. Results, 102: College Station, TX (Ocean Drilling Program), 29-47.

Busch, W.H., Castillo, P.R., Floyd, P.A., and Cameron, G., 1992. Effects of alteration of physical properties of basalts from the Pigafetta and East Mariana basins. In Larson, R.L., Lancelot, Y., et al., Proc. ODP, Sci. Results, 129: College Station, TX (Ocean Drilling Program), 485-499.

Carlson, R.L., and Herrick, C.N., 1990. Densities and porosities in the oceanic crust and their variations with depth and age. J. Geophys. Res., 95:91539170.

Castillo, P.R., Floyd, P.A., France-Lanord, C., and Alt, J.C., 1992. Data Report: Summary of geochemical data for Leg 129 igneous rocks. In Larson, R.L., Lancelot, Y., et al., Proc. ODP, Sci. Results, 129: College Station, TX (Ocean Drilling Program), 653-670.

Christensen, N.I., Blair, S.C., Wilkens, R.H., and Salisbury, M.H., 1980. Compressional wave velocities, densities, and porosities of basalts from Holes 417A, 417D, and 418A, Deep Sea Drilling Project Legs 51-53. In Donnelly, T., Francheteau, J., Bryan, W., Robinson, P., Flower, M., Salisbury, M., et al., Init. Repts. DSDP, 51, 52, 53 (Pt. 2): Washington (U.S. Govt. Printing Office), 1467-1471.

Christensen, N.I., and Salisbury, M.H., 1972. Sea floor spreading, progressive alteration of layer 2 basalts, and associated changes in seismic velocities. Earth Planet. Sci. Lett., 15:367-375.

Ekstrom, M.P., Dahan, C.A., Chen, M.-Y., Lloyd, P.M., and Rossi, D.J., 1986. Formation imaging with microelectrical scanning arrays. Trans. SPWLA 27th Annu. Logging Symp., Pap. BB.

Fisher, A., Becker, K., Narasimhan, T.N., Langseth, M., and Mottl, M., 1990. Passive, off-axis convection on the southern flank of the Costa Rica Rift. J. Geophys. Res., 95:9343-9370.

Floyd, P.A., and Castillo, P.R., 1992. Geochemistry and petrogenesis of Jurassic ocean crust basalts, Site 801. In Larson, R.L., Lancelot, Y., et al., Proc. ODP, Sci. Results, 129: College Station, TX (Ocean Drilling Program), 361-388.

Gassmann, F., 1951. Elastic waves through a packing of spheres. Geophysics, $16: 673-685$.

Hamilton, E.L., 1976. Variations of density and porosity with depth in deep-sea sediments. J. Sediment. Petrol., 46:280-300.

Hart, R.A., 1973. A model for chemical exchange in the basalt-seawater system of oceanic layer II. Can. J. Earth Sci., 10:799-816.

Houtz, R., and Ewing, J., 1976. Upper crustal structure as a function of plate age. J. Geophys. Res., 81:2490-2498.

Hyndman, R.D., Christensen, N.I., and Drury, M.J., 1984. The physical properties of basalt core samples from Deep Sea Drilling Project Leg 78B Hole 395A. In Hyndman, R.D., Salisbury, M.H., et al., Init. Repts. DSDP, 78 (Pt. 2): Washington (U.S. Govt. Printing Office), 801-810.

Hyndman, R.D., and Drury, M.J., 1976. The physical properties of oceanic basement rocks from deep drilling on the Mid-Atlantic Ridge at $23^{\circ} \mathrm{N} . J$. Geophys. Res., 81:4042-4052.

Jarrard, R.D., and Broglia, C., 1991. Geophysical properties of oceanic crust at Sites 768 and 770. In Silver, E.A., Rangin, C., von Breymann, M.T., et al., Proc. ODP, Sci. Results, 124: College Station, TX (Ocean Drilling Program), 75-90.

Jarrard, R.D., and Schaar, R., 1991. Electrical properties of basalts from Site 768 and 770. In Silver, E.A., Rangin, C., von Breymann, M.T., et al., Proc. ODP, Sci. Results, 124: College Station, TX (Ocean Drilling Program), 91-104.

Kennett, B.L.N., and Orcutt, J.A., 1976. A comparison of travel time inversions for marine refraction profiles. J. Geophys. Res., 81:4061-4070.

Kirkpatrick, R.J., 1978. Results of downhole geophysical logging Hole 396B, DSDP Leg 146. In Dmitriev, L., Heirtzler, J., et al., Init. Repts. DSDP, 46: Washington (U.S. Govt. Printing Office), 401-407.

Kuster, G.T., and Toksöz, M.N., 1974. Velocity and attenuation of seismic waves in two-phase media: Part I - theoretical formulations. Geophysics, 39:587-606.

Lüthi, S.M., and Banavar, J.R., 1988. Application of borehole images to three-dimensional geometric modeling of eolian sandstone reservoirs, Permian Rotliegende, North Sea. AAPG Bull., 72:1074-1089.

Lysne, P., 1989. Investigation of neutron-porosity log uncertainties: Ocean Drilling Program Hole 642E. In Eldholm, O., Thiede, J., Taylor, E., et al., Proc. ODP, Sci. Results, 104: College Station, TX (Ocean Drilling Program), 973-977.

Molinie, A.J., and Ogg, J.G., 1992. Data Report: Formation microscanner imagery of Lower Cretaceous and Jurassic sediments from the western Pacific (Site 801). In Larson, R.L., Lancelot, Y., et al., Proc. ODP, Sci. Results, 129: College Station, TX (Ocean Drilling Program), 671-691.
Moos, D., 1990. Petrophysical results from logging in DSDP Hole 395A, ODP Leg 109. In Detrick, R., Honnorez, J., Bryan, W.B., Juteau, T., et al. Proc. ODP, Sci. Results, 106/109: College Station, TX (Ocean Drilling Program), 237-253.

Moos, D., Pezard, P., and Lovell, M., 1990. Elastic wave velocities within oceanic layer 2 from sonic full waveform logs in Deep Sea Drilling Project Holes 395A, 415A, and 504B. J. Geophys. Res., 95:9189-9207.

Olhoeft, G.R., 1981. Electrical properties of rocks. In Touloukian, Y.S., Judd, W.R., and Roy, R.F. (Eds.), Physical Properties of Rocks and Minerals: New York (McGraw-Hill), 257-330.

Pezard, P.A., 1990. Electrical properties of mid-ocean ridge basalt and implications for the structure of the upper oceanic crust in Hole 504B. $J$. Geophys. Res., 95:9237-9264.

Pringle, M.S., 1992. Radiometric ages of basaltic basement recovered at Sites 800, 801, and 802, Leg 129, western Pacific Ocean. In Larson, R.L., Lancelot, Y., et al., Proc. ODP, Sci. Results, 129: College Station, TX (Ocean Drilling Program), 389-404.

Purdy, G.M., 1983. The seismic structure of $140 \mathrm{Myr}$ old crust in the western central Atlantic Ocean. Geophys. J. R. Astron. Soc., 72:115-137.

Raymer, L.L., Hunt, E.R., and Gardner, J.S., 1980. An improved sonic transit time-to-porosity transform. Trans. SPWLA 21st Annu. Log. Symp., Pap. P.

Sager, W.W., Fullerton, L.G., Buffler, R.T., and Handschumacher, D.W., 1992. Argo Abyssal Plain magnetic lineations revisited: implications for the onset of seafloor spreading and tectonic evolution of the eastern Indian Ocean. In Gradstein, F.M., Ludden, J.N., et al., Proc. ODP, Sci. Results, 123: College Station, TX (Ocean Drilling Program), 659-669.

Salisbury, M.H., Donnelly, T.W., and Francheteau, J., 1980. Geophysical logging in Deep Sea Drilling Project Hole 417D. In Donnelly, T., Francheteau, J., Bryan, W., Robinson, P., Flower, M., Salisbury, M., et al., Init. Repts. DSDP, 51, 52, 53 (Pt. 1): Washington (U.S. Govt. Printing Office), 705-713.

Schreiber, E., and Fox, P. J., 1976. Compressional wave velocities and mineralogy of fresh basalts from the FAMOUS area and the Oceanographer Fracture zone and the texture of Layer 2A of the oceanic crust. J. Geophys. Res., 81:4071-4076.

, 1977. Density and P-wave velocity of rocks from the FAMOUS region and their implication to the structure of the oceanic crust. Geol. Soc. Am. Bull., 88:600-608.

Serra, O., 1984. Fundamentals of Well Log Interpretation (Vol. 1): The Acquisition of Logging Data: Amsterdam (Elsevier).

- 1986. Fundamentals of Well Log Interpretation (Vol. 2): The Interpretation of Logging Data: Amsterdam (Elsevier).

Shipboard Scientific Party, 1981. Site 462: Nauru Basin, Western Pacific Ocean, DSDP Leg 61. In Larson, R.L., Schlanger, S.O., et al., Init. Repts. DSDP, 61: Washington (U.S. Govt. Printing Office), 19-395.

1987. Site 645. In Srivastava, S.P., Arthur, M., et al., Proc. ODP, Init. Repts., 105: College Station, TX (Ocean Drilling Program), 61-418. 1990a. Site 765. In Ludden, J.N., Gradstein, F.M., et al., Proc. $O D P$ Init. Repts., 123: College Station, TX (Ocean Drilling Program), 63-267. 1990b. Site 801. In Lancelot, Y., Larson, R.L., et al., Proc. ODP, Init. Repts., 129: College Station, TX (Ocean Drilling Program), 91-170.

Toksöz, M.N., Cheng, C.H., and Timur, A., 1976. Velocities of seismic waves in porous rocks. Geophysics, 41:621-645.

Vera, E.E., and Mutter, J.G., 1988. Crustal structure in the Rose area of the East Pacific Rise: one-dimensional travel time inversion of sonobuoys and expanded spread profiles. J. Geophys. Res., 93:6635-6648.

Wallick, B.P., Christensen, N.I., and Ballotti, D.M., 1992. High-pressure velocity measurements of Jurassic basalt, Leg 129. In Larson, R.L., Lancelot, Y., et al., Proc. ODP, Sci. Results, 129: College Station, TX (Ocean Drilling Program), 501-506.

Winsauer, W.O., and McCardell, W.M., 1953. Ionic double-layer conductivity in reservoir rocks. Petrol. Trans. AIME, 198:129-134.

Wyllie, M.R.J., Gregory, A.R., and Gardner, L.W., 1956. Elastic wave velocities in heterogeneous and porous media. Geophysics, 21:41-70.

Date of initial receipt: 26 January 1994

Date of acceptance: 22 September 1994 Ms 144SR-025 